\title{
Konferencja Naukowo-Szkoleniowa XVIII Dni Otolaryngologii Dziecięcej, 23-25 maja 2013 r., Uniwersytet Medyczny, tódź
}

\section{Wykłady}

\section{Anna Bielicka, Beata Zielnik-Jurkiewicz \\ Zapalenie jamy nosowo-gardłowej $\mathrm{w}$ aspekcie zakażenia atypowego i udziału Chlamydophila pneumoniae}

Oddział Otolaryngologiczny, SZPZOZ

im. Prof. J. Bogdanowicza, Warszawa

Przewlekłe zapalenie tkanki migdałka gardłowego przebiegające zwykle z jego nadmiernym przerostem jest jedną $\mathrm{z}$ częstszych chorób wieku dziecięcego. Zakażenie to spowodowane jest przede wszystkim przez patogenne bakterie tlenowe, takie jak Streptococcus pneumoniae, Haemophilus influenzae, Moraxella catarrhalis, Streptococcus pyogenes, ale pojawiają się też doniesienia, w których podkreśla się możliwość udziału Chlamydophila pneumoniae w patologii migdałka gardłowego. C. pneumoniae jest Gram-ujemną bakterią tworzącą wtręty w cytoplazmie zakażonych komórek. Bakteria ta posiada unikalny cykl rozwojowy obejmujący występowanie w postaci ciałka elementarnego oraz ciałka siateczkowatego. C. pneumoniae może też występować $\mathrm{w}$ postaci form przetrwałych w monocytach, komórkach nabłonka, komórkach układu nerwowego. Diagnostyka zakażeń wywołanych przez C. pneumoniae, oparta na hodowlach komórkowych, badaniach serologicznych, metodach molekularnych oraz metodach wykrywających antygen, nie jest dostępna w codziennej praktyce klinicznej i ambulatoryjnej. Powinowactwo do komórek nabłonka i limfocytów, zdolność do uszkadzania rzęsek nabłonka dróg oddechowych i występowania $\mathrm{w}$ formie przetrwałej, niewrażliwej na antybiotyki, oraz hamowanie apoptozy komórek gospodarza to cechy C. pneumoniae, które mogą mieć związek z przewlekłym stanem zapalnym migdałka gardłowego i jego przerostem. Przedstawiono wyniki badań własnych, których głównym celem było wykazanie obecności C. pneumoniae w migdałku gardłowym u dzieci zakwalifikowanych do planowej adenoidektomii. Grupę badaną stanowiło 200 dzieci w wieku od 2 do 16 lat (śr. wiek 6,38). Tkankę migdałka gardłowego badano metodą real-time PCR. Migdałki pobrane od dzieci z dodatnim wynikiem badania metodą PCR oraz od 10 losowo wybranych dzieci z ujemnym wynikiem tego badania oceniono, stosując badanie immunohistochemiczne (IHC) oraz badanie histopatologiczne. Obecność DNA C. pneumoniae w migdałku gardłowym stwierdzono u 5,5\% dzieci.
Dodatnie wyniki uzyskiwano najczęściej $(24,14 \%)$ w grupie wiekowej od 10 do 16 roku życia. Wykazano zależność między występowaniem $C$. pneumoniae w migdałku gardłowym a wiekiem dziecka i złymi warunkami socjoekonomicznymi.

Mieczysław Chmielik, Lidia Zawadzka-Głos, Lechosław Paweł Chmielik, Magdalena Frąckiewicz Sesja V

\section{PZZP u dzieci}

Klinika Otolaryngologii Dziecięcej Warszawskiego Uniwersytetu Medycznego

Infekcje górnych dróg oddechowych są najczęstszymi schorzeniami u człowieka. W wieku rozwojowym występują one częściej niż u dorosłych. Dlatego właściwe ich rozpoznanie i leczenie stanowi dla lekarza domowego, pediatry czy laryngologa dziecięcego szczególny problem. Etiopatogeneza tych schorzeń u dzieci jest niejasna i stanowi od dziesięcioleci wyzwanie dla lekarzy teoretyków i praktyków. Mechanizmy rozwoju schorzenia u dzieci zależą zarówno od możliwości obronnych organizmu, warunków życia czy sytuacji epidemiologicznej w danym regionie. Mechanizmy te nie są łatwe do sprecyzowania, a zwłaszcza do wyciągania wniosków klinicznych. Dlatego też różne ośrodki zajmujące się tymi problemami wypracowały niekiedy odmienne podejście teoretyczne i praktyczne. Próby usystematyzowania tematu podejmowane $\mathrm{w}$ literaturze, a zwłaszcza podczas kongresów i sympozjów poświęconych tym sprawom nie przyniosły jasnego skonkretyzowania problemu. Przyznają to nawet autorzy konsensusu z Brukseli z 1996 roku, czy EPOS z roku 2007. Problemy wynikają ze współistnienia różnych czynników, które mają wpływ na rozwój i przebieg choroby. Do najlepiej określonych należą te postaci schorzenia, które wynikają ze stałego utrudnienia w oddychaniu przez nos, np. przerostu migdałka, skrzywienia przegrody nosa wrodzonego zwężenia tej okolicy. Większość autorów jest tu zgodna, że wstępem do leczenia schorzenia powinno być operacyjne udrożnienie jam nosa czy ujść zatok przynosowych. Ta przyczyna schorzenia najpełniej odpowiada definicji PZZP u dzieci, tj. schorzenia, które występuje stale, bez cech sezonowości. Objawia się stałym lub często nawracającym wyciekiem śluzopochodnym z nosa, upośledzeniem drożności nosa, kaszlem napadowym, zwykle rano, wieczorem czy po wysiłku, oraz objawami ogólnymi: nerwowością, męczliwością, 
potliwością, zaburzeniami koncentracji uwagi, nadruchliwością. Definicję tę spełniają, jak wspomniano, schorzenia u pacjentów z blokadą mechaniczną w obrębie nosa czy ujść zatok przynosowych. Jest jednak znaczny odsetek dzieci, które demonstrują te same objawy przy zachowanej anatomicznej możliwości oddychania przez nos. Są wśród nich dzieci $\mathrm{z}$ alergią, dzieci z mukowiscydozą czy zaburzoną ruchomością rzęsek, jednak najliczniejszą grupą są dzieci w wieku 5-12 lat bez wspomnianych powyżej schorzeń, które jednak przez 6-8 miesięcy w roku spełniają definicję wspomnianego już PZZP. Jednak w miesiącach letnich objawy te ustępują całkowicie. Dzieci te sprawiać mogą lekarzowi problemy diagnostyczne i lecznicze, gdyż czynniki wywołujące schorzenia są liczne i nie do końca sprecyzowane. Stąd trudności w opracowaniu wspomnianych standardów leczenia dla tych schorzeń w wieku rozwojowym. Celem doniesienia będzie przedstawienie słuchaczom zarówno aktualnych opracowań z literatury, jak i przedstawienie własnych opartych o wiele dziesięcioleci doświadczeń kliniki w tej dziedzinie.

\section{Zsuzsanna Csákányi}

\section{Sesja I}

\section{Risk for the development of middle ear structural lesions in children with prolonged OME. Potential prognostic factors of the clinical course}

\author{
Zsuzsanna Csakanyi ${ }^{1}$, Denes Konya ${ }^{2}$, FerencMohos ${ }^{3}$, \\ Istvan Sziklai ${ }^{4}$, Gabor Katona ${ }^{1}$ \\ ${ }^{1}$ Department of Pediatric Otorhinolaryngology, Heim Pal \\ Children's Hospital, Budapest, Hungary \\ ${ }^{2}$ Budapest University of Technology and Economics, Budapest, \\ Hungary \\ ${ }^{3}$ University of Szeged, Faculty of Engineering, Szeged, Hungary \\ ${ }^{4}$ Department of Otorhinolaryngology and Head and Neck \\ Surgery, Health Science Centre, University of Debrecen, \\ Debrecen, Hungary
}

Background: 5-10\% of OME cases may develop chronic otitis media with structural changes. The benefits of grommet insertion are controversial. We have shown that mastoid volumes of healthy and OME patients differ significantly. The mastoid developmental rate is very low in OME. Intractable cases have the smallest mastoid volu$\mathrm{me}$, at $\leq 3 \mathrm{ml}$.

Objective: To analyze middle ear gas pressure changes in normal and pathological conditions. To explore potential prognostic factors of unfavorable clinical course. Methods: We used a mathematical model to predict the development of middle ear gas pressure balance as a function of different middle ear volumes (VME), considering normal and dysfunctional Eustachian tube. We applied published data as gas pressure input values and considered our 3D CT reconstruction data in healthy and pathological middle ears of children.

Results: The mathematical model predicts a dynamic pressure balance stabilizing with $\leq 0.5 \mathrm{mmHg}$ pressure fluctuations in a $\mathrm{VME} \geq 3 \mathrm{ml}$, compared to that of $\geq 1.2 \mathrm{mmHg}$ in the VME $\leq 3 \mathrm{ml}$ for perfect ET function. In the case of prolonged ET dysfunction, pressure fluctuations in a VME $\leq 3 \mathrm{ml}$ can be 10-30 times larger than those of $\mathrm{VME} \geq 3 \mathrm{ml}$, which may facilitate structural changes.

Conclusion: In ears with reduced puffer capacity, duration of ET dysfunction determines the clinical course. Grommets can be beneficial for $\mathrm{VME} \geq 3 \mathrm{ml}$ and at younger ages. Prognosis is poor for VME $\mathrm{P} \leq 3 \mathrm{ml}$ with increased age and more grommets in the child's history.

Mark Haggard Sesja rozpoczęcia

\section{Selecting children who benefit most from treatments: a clinical and scientific challenge}

Wydział Psychologii Uniwersytetu w Cambridge

The database from the UK medium-sized RCT (TARGET, $\mathrm{N}=376$ randomised in age-range $2.5-7 \mathrm{yrs}$ ) with rich data offers pediatric ORL a rare set of scientific opportunities. The usual as-randomised ('ITT') analysis is simple and unbiased; despite some dilution through variation of treatment continuing bad cases insisting on eventual treatment), it is powerful. By hypothesising relevant sub-groups, treatment effect sizes can be compared in groups that would and would not be treated under any specifiable policy, and p-value is placed on the reliability of this distinction via the interaction term (ie difference in differences). Far from there being no interactions (as reported in some trials and meta-analyses not equipped to address this central clinical issue) there are many ways of expressing two fundamental and separate processes for the determination of benefit: VTs benefit those with most lasting conductive loss and adjuvant adenoidectomy benefits those qualifiers (20+ dBHL, two occasions 3 months apart) who furthermore have URTI frequency, rather than enduring effusion once infected, as their main OME driver. Three new findings have recently emerged from this strand of work on evidence-based indications for the VT component of surgery. (1) Taking the parentally reported hearing difficulties (RHD) as indicator confirms the previous general finding that about $90 \%$ of qualifiers do benefit, so should be treated. This is high enough to ask: is the further assessment required to delimit the benefitting $90 \%$ worthwhile if it only saves $\sim 10 \%$ of operations among those qualifying ? Before needing to balance costs of assessment against savings in operations, we can answer this with a YES. The interaction is cross-over in form: mild HARM to HL occurs among the mildest $10 \%$ of qualifiers who would be given immediate VTs: they do WORSE than a watchful waiting control group. Thus a further stage of assessment IS needed after qualification. (2) Comparing a wide range of policies with differing cut-offs for VTs and adjuvant +adenoidectomy, a small set of optimum policies can be offered, permitting a choice according to resource level or operating theatre capacity. Sets of possible policies in which age contributes a component to the treatment recommendation, both re VTs and +adenoidectomy, distribute benefit to the caseload better than polices which ignore age, even in the narrowed range above 3.5 years. 
(3) Within this framework, a new composite indicator involving RHD and HL is simpler and more powerful than a previous one (involving also assessment of pars tensa retraction). Interestingly, timing is all-important for this indication. The HL has to be taken from the timing on entry into 3 months' watchful waiting, and the RHD at the end of this period. If the reverse is done (ie RHD from beginning and HL from the end) the ability to select benefitting children is much weaker, insufficient to recommend. The correlation between the averages with these different sequences for the same measures is quite low (0.34) and there is an explanation for why. Unfortunately, this means that RHD on a small number of questions cannot be used as simple community-based triage to decide whether a child should be sent for audiometry; informed referral, audiometry, and watchful waiting remain necessary.

\section{Mark Haggard, Jan Zirk-Sadowski}

\section{Sesja XII}

\section{Sprawić, by liczby liczyły (się): aktualności w metodach analiz dla klinicystów}

Wydziat Psychologii Uniwersytetu w Cambridge

Statystyka jest częścią (raczej niż całością) metody naukowej i zmienia się wraz z innowacjami i zmianami podejścia. Techniki planowania wydajnych badań nie mogą być tajemnicze, zniechęcające lub wywoływać wyobcowanie, alienację klinicystów. W przeszłości nauczanie procedur formalnych skupione było na unikaniu pozytywnych konkluzji z nieadekwatnego dowodu (błąd wnioskowania Typu 1), poprzez świadomość artefaktów i powszechnych błędów nieusystematyzowanego rozumowania i nadużywania formalnego testowania hipotez, które przyniosło fałszywe poczucie bezpieczeństwa. Ważne jest też, by nie wyciągać konkluzji zerowych (błąd wnioskowania Typu 2, gdy prawdziwe efekty są w rzeczywistości obecne. Z dobrą równowagą pomiędzy tymi zagrożeniami, statystyka wyłania się jako pomocny zbiór technik nabywania godnych zaufania dowodów wyrażania 'zasadnej argumentacji', jak to określił jeden $\mathrm{z}$ autorów.

Możemy wyróżnić dwa poziomy potrzeby wiedzy i umiejętności, (a) pierwszy dotyczy wszystkich klinicystów, którzy potrzebują krytycznej oceny jakości dowodu wobec twierdzeń przedstawionych w literaturze, (b) drugi dotyczy aktywnych badaczy, wymagających bardziej fundamentalnego zrozumienia pojęć pomiaru i niepewności, pozwalającego na przemyślaną, dobrze zorientowaną dyskusję z profesjonalnym statystykiem lub metodologiem, gdy pojawiają się pewne nietypowe problemy. Celem tego 1 -godzinnego warsztatu nie jest szczegółowe instruowanie słuchaczy odnośnie korzystania z szeregu nowoczesnych technik statystycznych. Warsztat pozwoli raczej na docenienie i zrozumienie, dlaczego niektóre szczególne techniki są potrzebne; a także pomoże zauważyć, jak w łatwy sposób można nauczyć się korzystać z udogodnień dostępnych w nowoczesnym oprogramowaniu. Wiadomości zostaną przedstawione w kontekście listy książek, artykułów i polskich oraz angielskich stron internetowych, by ułatwić dalsze nabywanie umiejętności.
Elżbieta Hassmann-Poznańska Sesja I

\section{Upośledzenie słuchu jako następstwo wysiękowego zapalenia ucha}

\author{
Klinika Otolaryngologii Dziecięcej Uniwersytetu Medycznego \\ w Białymstoku
}

Wprowadzenie: Przewlekłe wysiękowe zapalenie ucha może być przyczyną zmian strukturalnych błony bębenkowej, co z kolei może powodować upośledzenie słuchu.

Cel: Audiometria wysokich częstotliwości pozwala na wykrycie nawet niewielkiego upośledzenia słuchu, dlatego celem pracy jest wykorzystanie tej metody w ocenie słuchu u dzieci z przebytym wysiękowym zapaleniem uszu.

Materiał i metody: Przeprowadzono badania grupy 97 chorych, którzy przed średnio 7 laty byli leczeni z powodu wysiękowego zapalenia ucha. U chorych przeprowadzono badanie videootoskopowe, tympanometrię, audiometrię tonalną w standardowym zakresie i wysokich częstotliwości. Wyniki badań porównano z grupą kontrolną otologicznie zdrowych uszu.

Wyniki: Do analizy badań słuchu wybrano uszy z tympanometrią A lub C1. Podzielono je na następujące grupy na podstawie obrazu wziernikowego: 1. miejscowa atrofia i/lub myringoskleroza - 78 uszu, 2. kieszenie retrakcyjne - 38 uszu, 3. bez zmian wziernikowych - 36 uszu. W porównaniu z grupą kontrolną w uszach bez zmian wziernikowych obserwowano jedynie podwyższenie progów w niskich częstotliwościach, do $1 \mathrm{kHz}$, natomiast uszy z myringosklerozą i kieszeniami retrakcyjnymi miały istotnie podwyższone progi w całym zakresie częstotliwości, a próg słuchu podwyższał się wraz ze wzrostem częstotliwości.

Wnioski: Efektem przebytego wysiękowego zapalenia ucha jest niewielkiego stopnia upośledzenie słuchu szczególnie wyraźne w wysokich częstotliwościach.

Krzysztof Kochanek

Sesja III

Trudności w oznaczeniu progu słyszenia dla $500 \mathrm{~Hz}$ za pomocą słuchowych potencjałów wywołanych pnia mózgu

Światowe Centrum Stuchu Instytutu Fizjologii i Patologii Stuchu w Kajetanach

Słuchowe potencjały wywołane pnia mózgu mają od wielu lat wysoką pozycję w diagnostyce zaburzeń słuchu u małych dzieci. Stosowane są przede wszystkim w ocenie progu słyszenia, ale również w badaniach przesiewowych noworodków oraz diagnostyce różnicowej. Powszechnie wiadomo, że badania progu słyszenia metodą ABR dla trzasku nie stwarzają w praktyce większych problemów, natomiast dużym problemem jest wiarygodna ocena progu słyszenia dla niższych częstotliwości, np. $500 \mathrm{~Hz}$. Zdarza się, że przy prawidłowym progu słyszenia $\mathrm{w}$ audiometrii tonalnej próg fali $\mathrm{V}$ dla trzasku jest prawidłowy, natomiast dla $500 \mathrm{~Hz}$ znacznie podwyższony. 
Wiesław Konopka

Sesja XVI

\section{Zastosowanie aparatów zakotwiczonych w kości (BAHA) u dzieci}

Klinika Otolaryngologii Instytutu Centrum Zdrowia Matki Polki $w$ Łodzi

Odkrycie w latach pięćdziesiątych przez profesora Branemarka zjawiska osseointegracji, czyli trwałego łączenia się żywej tkanki kostnej z tlenkami tytanu pokrywającymi powierzchnię wszczepów, zapoczątkowało dynamiczny rozwój technik implantacyjnych w różnych dziedzinach medycyny.

W 1977 roku w Goeteborgu po raz pierwszy wszczepiono pacjentowi implant tytanowy, na którym umocowano aparat słuchowy na przewodnictwo kostne. W Polsce pierwszy implant typu BAHA wszczepił prof. Rydzewski w 1994 r.

Obecnie ta metoda leczenia niedosłuchów i głuchot jest uznaną i szeroko stosowaną w świecie techniką. W 1977 roku prof. Vanecloo rozpoczął stosowanie implantów BAHA w głuchocie jednostronnej. Wskazania do stosowania aparatu BAHA są podobne u dzieci i u dorosłych. Granicą u dzieci jest najczęściej grubość kości czaszki. Optymalny wiek to $>5$ lat.

Najczęstsze wskazania to: przewlekłe zapalenia uszu, wrodzone i nabyte atrezje ucha zewnętrznego, mikrocja, choroby ucha środkowego, guzy n. słuchowego, stan po usunięciu guza n. VIII, nagła głuchota, urazy piramidy kości skroniowej, zespoły wad genetycznych (zespół Treachera-Collinsa i inne), pacjenci z obustronnymi ubytkami słuchu typu przewodzeniowego lub mieszanego, którzy nie mogą korzystać z klasycznych aparatów na przewodnictwo powietrzne (chroniczne, niepoddające się leczeniu stany zapalne ucha środkowego $\mathrm{z}$ wyciekami, przewlekłe stany zapalne skóry przewodów słuchowych zewnętrznych (np. zmiany egzemowe), radykalne operacje uszu, otoskleroza (w przypadku braku możliwości leczenia operacyjnego).

Wymogi audiologiczne - przewodzeniowy niedosłuch - średnia dla przewodnictwa kostnego w operowanym uchu większa lub równa $45 \mathrm{~dB} \mathrm{HL}$, dyskryminacja mowy $\mathrm{w}$ teście jednosylabowym $\geq 60 \%$, przy obuusznym protezowaniu symetryczne przewodnictwo kostne. Mieszane uszkodzenie słuchu rezerwa ślimakowa $\geq 30 \mathrm{~dB}$, czuciowo odbiorczy komponent $<65$ dB.W jednostronnej głuchocie (SSD - Single Sided Deafness) drugie ucho prawidłowo słyszące (AC PTA > $20 \mathrm{~dB}$ HL - średnia dla częstotliwości: 0,$5 ; 1 ; 2$ i $3 \mathrm{kHz}$ ) i głęboki niedosłuch w uchu kontrlateralnym.

W przypadku stosowania implantów BAHA u dzieci istotne jest branie pod uwagę następujących zasad: jeżeli planowana jest rekonstrukcja małżowiny usznej - odpowiednie zaplanowanie miejsca na implant, jedno- lub dwuetapowa procedura chirurgiczna - proces gojenia i osteointegracji a następnie dopasowanie procesora, w międzyczasie można zastosować procesor na opasce. Osobiście preferuję procedurę jednoetapową. Istotnym jest rozważenie rodzaju cięcia - linijne lub z zastosowaniem dermatomu. W moim przekonaniu szczególnie u dzieci cięcie linijne jest zdecydowanie lepsze. Grubość kości a długość implantu to kolejny dylemat u dzieci, u których bardzo często grubość kości jest mniejsza lub równa $3 \mathrm{~mm}$. Należy wówczas rozważyć zastosowanie implantu 3 lub 4 mm.

W przypadku SSD szczególnie u dzieci istotna jest motywacja pacjenta i świadoma decyzja pacjenta poprzedzona oceną korzyści po zastosowaniu BAHA na opasce.

Dopasowanie procesora dźwięku u dzieci po 3-6 tygodniach od zabiegu powinno być poprzedzone oceną stopnia stabilizacji implantu.

Aneta Krogulska Sesja II

\section{Kiedy kaszel jest astmą?}

Klinika Alergologii, Gastroenterologii i Żywienia Dzieci Uniwersytetu Medycznego w Łodzi

Kaszel, czyli gwałtowne uwolnienie powietrza nagromadzonego w drogach oddechowych, jest skomplikowanym zjawiskiem fizjologicznym, pozostając jednocześnie podstawowym mechanizmem oczyszczającym drogi oddechowe $\mathrm{z}$ niepożądanych substancji inhalowanych $\mathrm{z}$ powietrzem do płuc. Według kryterium czasowego u dzieci do lat 15 kaszel określa się mianem przewlekłego, jeśli trwa powyżej 4 tygodni, natomiast u dzieci >15 lat, jeśli trwa powyżej 8 tygodni. Szacuje się, że kaszel przewlekły dotyczy 6-7\% populacji. Ze względu na możliwość licznych powikłań, kaszel przewlekły wymaga szybkiej i precyzyjnej diagnostyki oraz wdrożenia właściwego postępowania terapeutycznego. Do podstawowych przyczyn należą: infekcje (wirusowe, bakteryjne, gruźlica); astma; aspiracja (GER, ciało obce); czynniki drażniące w środowisku (np. dym tytoniowy); przewlekłe zapalenie zatok; mukowiscydoza czy wrodzona wada serca. Kaszel w przebiegu astmy jest zazwyczaj: suchy, męczący, napadowy, niekiedy występujący z dusznością, ze zmiennością dobową, sezonowością w ciągu roku, często współistniejący z ANN i AZS, nasilający się po ekspozycji na: alergeny, czynniki drażniące, po wysiłku, po hiperwentylacji, pod wpływem emocji lub zmian temperatury powietrza, w nocy. Ponadto występuje u pacjentów $\mathrm{z}$ często dodatnim osobniczym bądź rodzinnym wywiadem alergicznym oraz nie ustępuje po antybiotykoterapii. By stwierdzić, że kaszel jest wynikiem przewlekłego zapalenia w przebiegu astmy, należy posługiwać się odpowiednimi kryteriami diagnostycznymi. Ze względu na szczególne trudności diagnostyczne i terapeutyczne, związane $\mathrm{z}$ naturalnym przebiegiem choroby, rozwojem fizjologicznym dziecka oraz rodzajem i częstością współwystępowania innych chorób, eksperci GINA wyodrębnili kryteria rozpoznawania astmy u dzieci do 5. rż. i powyżej. U dzieci do 5. rż. rozpoznanie astmy opiera się na: danych klinicznych (objawy astmy i ocena API - klinicznego indeksu przewidywania astmy), weryfikacji rozpoznań innych niż astma oraz efektach terapii zastosowanej w celu diagnostycznym. Do podstawowych objawów astmy należą: kaszel, świszczący oddech (powinien być potwierdzony przez personel medyczny), duszność. U 75\% dzieci zazwyczaj obecny jest jeden z objawów: kaszel, duszność lub wheezing. Typowym objawem 
są również tzw. przeziębienia „schodzące na płuca” lub trwające dłużej niż 10 dni. U dzieci najmłodszych astma rozpoczyna się zwykle pod postacią nawrotowej lub przewlekającej się obturacji oskrzeli wywołanej zakażeniem wirusowym dróg oddechowych. Rozpoznanie astmy u dzieci $>5$. rż. opiera się na: badaniu podmiotowym i przedmiotowym oraz badaniach czynnościowych układu oddechowego. Prawidłowy wynik badań czynnościowych nie wyklucza astmy, a wynik nieprawidłowy nie przesądza o jej obecności. Z kolei ujemny wynik testu nieswoistej prowokacji oskrzeli może pomóc wykluczyć rozpoznanie astmy, natomiast wynik dodatni nie zawsze oznacza, że pacjent na nią choruje. Właściwe rozpoznanie warunkuje możliwość ustalenia odpowiedniego leczenia przyczynowego.

\section{Antoni Krzeski, Eliza Brożek-Mądry Sesja VII Przewlekłe zapalenie zatok przynosowych u dzieci - aspekty chirurgiczne}

\author{
Klinika Otolaryngologii Wydział Lekarsko-Dentystyczny \\ Warszawskiego Uniwersytetu Medycznego
}

Przewlekłe zapalenie zatok przynosowych u dzieci nie stanowi tak dobrze przebadanej jednostki jak w przypadku dorosłych, stąd leczenie tych pacjentów wciąż dostarcza wielu dylematów w codziennej praktyce. W populacji dziecięcej dużą wagę przypisuje się roli migdałka gardłowego, który traktowany jest jako rezerwuar bakterii, włączając w to możliwość powstawania biofilmu na jego powierzchni. Filarem leczenia jest postępowanie zachowawcze, podczas gdy leczenie chirurgiczne zarezerwowane jest dla tej grupy pacjentów, którzy nie reagują na leczenie farmakologiczne.

Wśród metod leczenia chirurgicznego na pierwszym miejscu wymienia się adenotomię. Poprawa po usunięciu migdałka gardłowego opisywana jest u 50 do $70 \%$ pacjentów. Niepowodzenia po adenotomii najczęściej dotyczą pacjentów w młodszej grupie wiekowej (poniżej 7. roku życia) oraz pacjentów z towarzyszącymi schorzeniami dolnych dróg oddechowych, takimi jak astma oskrzelowa. W świetle ostatnich badań potwierdza się, że lepszy wynik leczenia można uzyskać, jeżeli wraz $\mathrm{z}$ adenotomią wykonane zostanie płukanie zatok szczękowych (do 78-88\%).

Nową metodą leczenia, z opisywanym wysokim odsetkiem poprawy, jest balonikowanie zatok szczękowych z poszerzaniem ujść tych zatok, natomiast dostępne dotychczas badania nie stanowią wystarczających dowodów przemawiających za wyborem tej metody przed adenotomią z płukaniem zatok szczękowych.

Nie uzyskując poprawy po wykonaniu jednej lub obu powyższych procedur, należy sięgnąć po zdobycze chirurgii endoskopowej i zaproponować pacjentowi funkcjonalną operację endoskopową zatok przynosowych. Leczenie endoskopowe w ok. 90\% przypadków (82-100\%) przynosi poprawę w zakresie występujących objawów. Wśród powikłań tej metody leczenia operacyjnego najczęściej stwierdzane są zrosty i zwężenie ujścia zatoki szczękowej.
Innej drogi postępowania operacyjnego wymagają pacjenci z mukowiscydozą, przewlekłym zapaleniem zatok przynosowych z polipami, śluzowiakiem, polipem antrochoanalnym, czy alergicznym grzybiczym zapaleniem zatok przynosowych. W tych jednostkach chorobowych należy w pierwszej kolejności podjąć się operacji endoskopowej zatok przynosowych celem zmniejszenia nasilenia objawów choroby.

W wykładzie zostanie omówiony zakres wykonywanych operacji endoskopowych wraz z prezentacją przypadków.

Jerzy Kuczkowski, Kazimierz Niemczyk Sesja III

\section{Nawracające zapalenie opon mózgowo- -rdzeniowych u dzieci w następstwie samoistnego płynotoku usznego}

\section{Klinika Otolaryngologii Gdańskiego Uniwersytetu Medycznego Klinika Otolaryngologii Warszawskiego Uniwersytetu Medycznego}

Samoistny płynotok uszny (spu) może być przyczyną nawracającego zapalenia opon mózgowo-rdzeniowych (zomr). Płynotok uszny wywołany jest urazem głowy lub wadą rozwojową kości skroniowej. Rozpoznanie oraz zlokalizowanie spu jest trudne we wczesnym dzieciństwie.

Celem pracy jest analiza kliniczna oraz omówienie postępowania w przypadku spu u dzieci z nawracającym zomr.

Materiał i metoda: Materiał stanowiło troje dzieci w wieku od 4 do 14 lat leczonych w Klinikach Otolaryngologii GUMed oraz WUM z powodu spu. Podejrzenie płynotoku wzbudziły nawracające epizody zomr w następstwie ostrego zapalenia ucha środkowego.

Wyniki: Rozpoznanie spu postawiono w oparciu o przeciek płynu m-r do jamy bębenkowej (potwierdzony badaniem biochemicznym). U dzieci wykazano jednostronny głęboki niedosłuch odbiorczy lub całkowitą głuchotę. Badania TK oraz MRI kości skroniowych wykazały ubytki w ścianach jamy bębenkowej oraz nieprawidłowości budowy ucha wewnętrznego. Próby zamknięcia płynotoku (szczeliny) przy pomocy tłuszczu własnego były nieskuteczne. Wykonanie petrosektomii bocznej z odsłonięciem przetoki, zamknięciem jej mięśniem z obliteracją jamy pooperacyjnej tłuszczem umożliwiło zamknięcie przetoki, które zapobiegło nawrotowi zomr.

Wnioski: Petrosektomia boczna z zamknięciem przetoki mięśniem oraz obliteracja tłuszczem jest skuteczną metodą leczenia spu, które zapobiega nawrotowi zapalenia opon m-r u dzieci. 
Jerzy Kuczkowski

Sesja XVI

\section{Proces niszczenia kości w przewlekłym zapaleniu ucha środkowego u dzieci. Aspekty chirurgiczne}

Klinika Otolaryngologii Gdańskiego Uniwersytetu Medycznego

Osteoliza jest częstym zjawiskiem w przewlekłym zapaleniu ucha środkowego u dzieci, a jej największe nasilenie występuje w zapaleniu perlakowym, rzadziej w kieszonkach retrakcyjnych. Rozległość ubytków kostnych świadczy o zaawansowaniu choroby. Osteoliza może występować zarówno w stawach i kosteczkach słuchowych, jak i w ścianach kostnych psz, jamie bębenkowej i sutkowej. Zniszczenie połączeń stawowych jak i ścian kostnych ucha może prowadzić do odsłonięcia opony, błędnika, stawu skroniowo-żuchwowego, obnażenia naczyń i nerwów oraz niedosłuchu. Osteolizę wywołuje zarówno zapalenie perlakowe oraz ziarninowe, jak i kieszonki retrakcyjne oraz tympanoskleroza. Niszczenie kości ucha w pzuś odbywa się na skutek ucisku rozrastającego się perlaka lub ziarniny oraz działania enzymów i cytokin. Osteoliza w uchu stymulowana jest przez bakteryjne czynniki infekcyjne. Rozpoznanie osteolizy ucha w pzuś umożliwiają badania pod mikroskopem, badania biochemiczne, histopatologiczne oraz tomografia komputerowa. Ostateczna ocena zaawansowania osteolizy możliwa jest w czasie operacji ucha. Leczenie zapalenia kości ucha jest bardzo trudne. Postępowanie zachowawcze polega na „zakwaszeniu ucha”, irygacji, aspiracji treści ropnej i złuszczonego naskórka oraz stosowaniu miejscowym leków bakteriostatycznych lub bakteriobójczych. Leczenie chirurgiczne polega na usunięciu perlaka, ziarniny, złogów tympanosklerozy, kieszonki retrakcyjnej oraz „wyfrezowaniu” zmienionej zapalnie kości. Skuteczność leczenia zależy od skrupulatności zabiegu usuwania zmienionej zapalnie kości ucha. Optymalnym sposobem jest usuwanie zmienionej zapalnie kości wiertłem diamentowym $\mathrm{z}$ użyciem mikroskopu i wypłukiwanie powierzchni solą fizjologiczną lub 10-proc. okteniseptem. Odbudowa ścian kostnych następuje po zakończeniu procesu „nabłonkowania”. Proces ten może być przyśpieszony po zapewnieniu właściwej wentylacji ucha, eradykacji zakażenia oraz usunięciu obcych biologicznie elementów z ucha.

Wojciech Kukwa, Adam Gałązka, Andrzej Kukwa, Tomasz Grochowski Sesja III

\section{Zaburzenia oddychania podczas snu u dzieci - przyczyny, objawy i konsekwencje}

Klinika Otolaryngologii Warszawskiego Uniwersytetu Medycznego

Zaburzenia oddychania podczas snu (ZOPS) w populacji dziecięcej są często występującym problemem. Podobnie jak u dorosłych wyróżnia się odmienne formy choroby, począwszy od prostego chrapania (ang. Primary Snoring - PS), poprzez zespół wzmożonej oporności górnych dróg oddechowych (UARS), do pełnego zespołu snu z bezdechami (OSA). Częstość występowania schorzenia określa się wśród dzieci w wieku przedszkolnym i szkolnym na 3-8\%.
W większości przypadków za zaburzenia oddychania podczas snu u dzieci odpowiedzialny jest przerost układu chłonnego gardła. Nie mniej istotna wydaje się być występująca u rosnącej liczby dzieci nadwaga i otyłość. Trwające wiele lat upośledzenie drożności nosa i będące tego konsekwencją oddychanie przez usta wpływa na nieprawidłowy rozwój twarzoczaszki dziecka i może przyczynić się do utrzymywania się zaburzeń oddychania u dziecka także po adenotomii/ adenotonsillotomii.

Lista objawów ZOPS u dzieci jest bardzo długa i nie ogranicza się jedynie do objawów nocnych takich jak chrapanie czy bezdechy. Badania prowadzone na dzieciach w wieku przedszkolnym i szkolnym wskazują, że ZOPS mogą w dużym stopniu przyczynić się do wystąpienia zaburzeń rozwoju psychicznego, zaburzeń rozwoju intelektualnego, rozwoju nadciśnienia tętniczego i płucnego, zaburzeń przepływu mózgowego i innych. Autorzy przedstawiają wyniki badania przesiewowego prowadzonego w województwie warmińsko-mazurskim, metodykę badania, jego założenia i uzyskane dane na podstawie oceny 1248 dzieci w I klasach szkół podstawowych.

Piotr Laz, Józef Mierzwiński

Sesja I

\section{Technika chirurgiczna leczenia kieszonek} retrakcyjnych, wyniki leczenia

\section{Oddział Otolaryngologii, Audiologii i Foniatrii Dziecięcej,} Dziecięcy Program Implantów Ślimakowych, Bydgoszcz

W prezentacji przedstawiono detale technik chirurgicznych (prezentacje filmowe) stosowanych przy leczeniu kieszonek retrakcyjnych. Kieszonki typ 1 - omówiono rodzaje drenów i sposób zakładania drenów wentylacyjnych w atelektatyczną błonę bębenkową w zależności od lokalizacji i rozległości zmian patologicznych. Kieszonki typ 2 - przedstawiono technikę przedłużonego drenażu drenem $\mathrm{T}$ oraz jednoczasowe rozdzielenie zrostu i podparcie atelektatycznej błony bębenkowej chrząstką. Kieszonki typ 3 - omówiono technikę tympanoplastyki zamkniętej stosowanej przy rozległych kieszonkach z masywnymi zrostami w tylnych częściach jamy bębenkowej i attyce jak również zasady stosowania chrząstki do wzmocnienia błony bębenkowej w tych przypadkach.

W omówieniu przedstawiono anatomiczne i czynnościowe wyniki stosowanych technik leczenia kieszonek retrakcyjnych.

Grażyna Mielnik-Niedzielska

Sesja IV

\section{Niedosłuch jednostronny a osiągnięcia szkolne}

Klinika Otolaryngologii Dziecięcej, Audiologii i Foniatrii Uniwersytetu Medycznego w Lublinie

Od początku lat osiemdziesiątych ubiegłego wieku po publikacji serii artykułów przez Bess i wsp. dotyczących 
wpływu jednostronnego niedosłuchu na rozwój mowy i języka spojrzenie na niedosłuch jednostronny ewaluowało. Pod koniec dwudziestego wieku Ruben i Schwartz wykazali, że niedosłuch jest integralnym komponentem prawidłowego rozwoju języka. Uczniowe z niedosłuchem jednostronnym wykazywali problemy z komunikacją receptywną wynikające $\mathrm{z}$ hałasu w tle i problemów z lokalizacją dźwięku. Dziecko z niedosłuchem jednostronnym ma połowę możliwości odbioru dźwięku (utrata połowy zmysłu słuchu). W niedosłuchu jednostronnym występuje efekt cienia, który sprawia, że ucho zdrowe jest mniej wrażliwe na sygnały dźwiękowe. Źródłem kolejnego słuchowego wyzwania jest osłabiona możliwość lokalizacji dźwięków, skutkiem takiego stanu jest nieumiejętność zorientowania się w polu dźwięków. Połączenie audiometrycznej utraty słuchu, efektu cienia dźwięku i utraty lokalizacji dźwięku powoduje zmniejszoną umiejętność rozróżniania sygnału w hałasie. Wyodrębnienie dźwięku z hałasu jest praktyczną miarą funkcji słyszenia. Badania wykazały, że osoby z jednostronnym niedosłuchem mają niską samoocenę, wzrasta natomiast u nich stres i przemęczenie wywołane zwiększonym wysiłkiem, aby słyszeć. Według w ostatnim czasie opublikowanych prac, aby promować rozwój wyższych dróg poznawczych i psychologicznych rozwijający się mózg wymaga bodźców sensorycznych celem stymulacji rozwoju drogi słuchowej. Osoby z upośledzeniem czuciowym takim jak niedosłuch jednostronny doświadczają reorganizacji korowej. Badania kolejne wykazały, że dzieci $\mathrm{z}$ niedosłuchem jednostronnym nie radzą sobie $\mathrm{w}$ procesie edukacji i wymagają dodatkowej pomocy w szkole. Niedosłuch prawostronny prowadził do większych trudności szkolnych niż niedosłuch lewostronny i obustronny lekkiego stopnia. W kontekście przytoczonych badań celem zapewnienia opieki medycznej dzieciom poprzez usuwanie barier dla rozwoju poznawczego logiczne staje się, by w sposób jednakowy traktować dzieci z niedosłuchem jednostronnym jak w przypadku obustronnego niedosłuchu.

\section{Grażyna Mielnik-Niedzielska}

\section{Sesja XIV}

\section{Nawracające ostre zapalenie ucha środkowego u dzieci: zapobieganie i leczenie}

\section{Klinika Otolaryngologii Dziecięcej, Audiologii i Foniatrii Uniwersytetu Medycznego w Lublinie}

Nawracające ostre zapalenie ucha (AOM) jest definiowane zazwyczaj jako dobrze udokumentowane trzy lub więcej epizodów w czasie sześciu miesięcy lub co najmniej cztery epizody zapalenia w ciągu roku. Niemowlęta, które miały pierwszy epizod choroby przed szóstym miesiącem życia, oraz dzieci posiadające rodzeństwo są bardziej narażone na ciężki przebieg choroby i nawrotowość. Wybór strategii postępowania $\mathrm{w}$ zapobieganiu nawrotowości powinny obejmować takie dane wywiadu jak: wystąpienie pierwszego epizodu OAM, pora roku, w której doszło do zachorowania, uczęszczanie do żłobka lub przedszkola, występowanie zapalenia ucha w rodzinie, rozwój poznawczy i językowy, jakość życia rodziny związana z chorobą. Edukacja rodziców mająca na celu zmniejszenie ekspozycji na czynniki ryzyka zapalenia ucha jest istotnym elementem profilaktyki. Ostre zapalenie ucha jest chorobą infekcyjną, ponieważ oba czynniki infekcyjne jak wirusy i bakterie prowadzą do zapalenia błony śluzowej ucha środkowego. W prewencji należy uwzględnić szczepienia coroczne przeciw grypie oraz pneumokokową szczepionkę skoniugowaną (PCV 13) u dzieci do drugiego roku życia. Dzieciom starszym poleca się szczepionkę PCV23. Randomizowane badania wykazały, że profilaktyczne stosowanie antybiotyków jest skuteczne w redukcji występowania nawrotów ostrego zapalenia ucha, częstości nawrotów oraz całkowitego czasu trwania ostrego zapalenia ucha. Profilaktyczne stosowanie antybiotyku powinno uwzględnić doustną formę podania Amoksycilliny w dawce $40 \mathrm{mg} / \mathrm{kg}$ masy ciała/na dobę. Antybiotykowa profilaktyka jest skuteczniejsza od drenażu zewnętrznego i adenoidectomii. Drugim akceptowanym podejściem jest zakładanie tubek wentylacyjnych, które zmniejszają częstość nawrotów i czas trwania stanu zapalnego ucha. Usunięcie migdałka gardłowego jest trzecię możliwością w zmniejszeniu liczby epizodów ostrego zapalenia ucha. Zabieg ten redukuje częstość nawrotów ostrego zapalenia ucha, jednakże nie powinien być stosowany do drugiego roku życia. Rekomendacje powyższe nie dotyczą dzieci z grup ryzyka, które wymagają indywidualnego podejścia.

Maciej Misiołek Sesja XVII

\section{Postępowanie operacyjne w zwężeniach krtani}

Katedra i Oddział Kliniczny Laryngologii w Zabrzu

Śląskiego Uniwersytetu Medycznego w Katowicach

Zwężenia w obrębie krtani należy podzielić na wrodzone i nabyte. Wśród tych ostatnich rozróżniamy pourazowe, jatrogenne i powstałe $\mathrm{w}$ wyniku różnych innych schorzeń. Odrębny podział dotyczy lokalizacji zwężenia w danym piętrze krtani.

Często mamy do czynienia ze zwężeniami krtaniowo-tchawiczymi, które zwykle wymagają postępowania operacyjnego w zespole laryngologiczno-torakochirurgicznym. Stanowią one szczególnie trudny problem leczniczy.

Zwężenia pourazowe - (urazy zewnętrzne) wymagają zaopatrzenia w trybie pilnym, często $z$ tracheotomią i założeniem bolca akrylowego lub rurki T do krtani i części tchawicy po wykonanej rekonstrukcji. Uszkodzenia jatrogenne - po zabiegach endoskopowych, intubacji (powstanie zrostów, ziarniny i blizn zwężających światło krtani).

Zwężenia po operacjach krtani z dostępu zewnętrznego (laryngektomie częściowe), obustronne porażenia fałdów głosowych (powikłania po operacjach tarczycy, operacjach kardiotorakochirurgicznych, idiopatyczne). W postępowaniu operacyjnym należy rozważyć możliwość wykonania operacji endoskopowej (klasycznej lub laserowej), z ostrzyknięciem długo działającym sterydem lub przyłożeniem mitomycyny $\mathrm{C}$ i/lub założeniem stentu silastikowego, bądź procedury z dostępu zewnętrznego, często z rekonstrukcją fragmentem żebra lub kości gnykowej wstawionej w tylny odcinek chrząstki pierścieniowatej. 
W podsumowaniu należy podkreślić konieczność perfekcyjnej współpracy zespołów anestezjologicznych, laryngologicznych i torakochirurgicznych w leczeniu zwężeń krtani/tchawicy. Zwrócono też uwagę na przydatność wielu nowoczesnych technologii w procesie diagnostycznym zwężeń krtani (TK, MRI, spirometria, pletyzmografia i CFD /computational fluid dynamics/), co wiąże się z udziałem radiologów, pulmonologów, a ostatnio również coraz częściej inżynierów.

Waldemar Narożny

\section{Specyfika zawrotów głowy i zaburzeń równowagi u dzieci}

\author{
Katedra i Klinika Otolaryngologii Gdańskiego Uniwersytetu \\ Medycznego
}

We wstępie autor przedstawia embriogenezę ucha wewnętrznego ze szczególnym uwzględnieniem rozwoju jego części przedsionkowej. Następne informacje poświęcone są rozwojowi (dojrzewaniu) układu nerwowego, w tym części przedsionkowej, u dzieci oraz korelacji zachodzących zmian anatomopatologicznych a danymi klinicznymi.

W części klinicznej autor przekazuje dane dotyczące epidemiologii i etiologii zawrotów głowy u dzieci, a następnie przedstawia symptomatologię najczęściej spotykanych w tej grupie wiekowej jednostek chorobowych. Ważnym zagadnieniem poruszanym przez autora jest wykazanie różnic istniejących między diagnostyką zawrotów głowy u dzieci a sposobami rozpoznawania tych dolegliwości u dorosłych.

W części końcowej autor formułuje główne zagadnienia diagnostyczno-kliniczne kształtujące specyfikę zawrotów głowy u dzieci.

\section{Olga Olszewska-Sosińska, Beata Zielnik-Jurkiewicz}

\section{Sesja VI}

\section{Kolonizacja, nosicielstwo i biofilm górnych dróg oddechowych u dzieci}

\section{Oddział Otolaryngologiczny, SZPZOZ \\ im. Prof. J. Bogdanowicza, Warszawa}

Flora bakteryjna górnych dróg oddechowych (gdo) poddana jest ciągłym zmianom, co bezpośrednio wiąże się z wiekiem dziecka, ekspozycją na czynniki środowiskowe, współwystępowaniem chorób przewlekłych i powtarzaną antybiotykoterapią. Kolonizacja gdo następuje u noworodka, a bakteriami kolonizującymi są saprofity bytujące w drogach rodnych i na skórze matki. Kolonizacja gdo przez saprofity jest swoistą obroną organizmu dziecka zapobiegającą inwazji patogenów. Saprofity zmniejszają ryzyko kolonizacji bakteriami chorobotwórczymi, których obecność u noworodka ze względu na niedojrzałość układu immunologicznego zwiększa ryzyko chorób inwazyjnych. Górne drogi oddechowe poza saprofitami kolonizują także bakterie chorobotwórcze, co daje korzyści związane $\mathrm{z}$ wczesną prezentację antygenów bakteryjnych komórkom immunologicznym gospodarza i zapewnia szybkie uruchomienie obrony immunologicznej w momencie zakażenia. Następstwem kolonizacji jest nosicielstwo, czyli długotrwała obecność bakterii, grzybów, pierwotniaków chorobotwórczych na powierzchni przy braku miejscowych i ogólnych objawów zakażenia. Nosicielstwo bakterii w gdo jest stanem fizjologicznym i nie wymaga leczenia. Antybiotykoterapia stosowana w nosicielstwie niszczy florę fizjologiczną zasiedlającą błonę śluzową gdo, stanowiącą naturalną obronę przed zakażeniami bakteriami chorobotwórczymi. Nosicielstwo bakterii u dzieci zdrowych i u dzieci z nawracającymi zapaleniami gdo różni się jakościowo i ilościowo. Nosicielstwo bakterii chorobotwórczych w tym wielolekoopornych w gdo zwiększa ryzyko zakażenia i sprzyja występowaniu ostrego zapalenia ucha środkowego czy zatok przynosowych, zwiększa zużycie antybiotyków i generuje antybiotykooporność. Identyfikacja nosicielstwa bakterii i grzybów najczęściej dokonywana jest w oparciu o posiewy bakteriologiczne i mykologiczne wymazów, homogenatów, z zastosowaniem metod diagnostyki molekularnej tj. PCR lub badania histopatologicznego. Badanie nosicielstwa u dzieci jest epidemiologicznie istotne, stanowiąc wyznacznik obecności, aktywności i zmienności bakterii oraz określa skuteczność szczepień i ich efektywność. Stała ocena nosicielstwa bakterii chorobotwórczych umożliwia ustalenie zasad skutecznej, racjonalnej antybiotykoterapii w zakażeniach gdo. Błona śluzowa gdo jest skolonizowana przez bakterie, grzyby i pierwotniaki. Na jej powierzchni obecne są drobnoustroje saprofityczne stanowiące florę fizjologiczną i drobnoustroje chorobotwórcze będące czynnikiem zakaźnym. Powszechnie dostępne w klinice metody diagnostyki mikrobiologicznej umożliwiają identyfikację bakterii i grzybów żyjących w postaci pojedynczych, niezależnych komórek tj. komórek planktonowych. To metody bardzo przydatne w diagnostyce ostrych zakażeń gdo, ale nie identyfikujące bakterii atypowych, L-form bakterii oraz biofilmów bakteryjnych i grzybiczych, odpowiedzialnych za występowanie przewlekłych zakażeń gdo. Dynamiczny rozwój mikroskopii elektronowej i technik biologii molekularnej przyczynił się do identyfikacji na powierzchni błony śluzowej górnych dróg oddechowych nie tylko bakterii atypowych czy L-bakterii, ale również nowych, wcześniej nieznanych form tj. biofilmów bakteryjnych i grzybiczych. Badania biofilmów na powierzchni błon śluzowych narządów laryngologicznych są nadal badaniami doświadczalnymi. Wszystkie dotychczas znane metody ich identyfikacji są drogie i niedostępne w codziennej praktyce. Biofilm zbudowany jest z bakterii lub grzybów otoczonych śluzowatą otoczką stanowiącą 90\% jego masy. Otoczka chroni bakterie lub grzyby przed niekorzystnymi czynnikami zewnętrznymi, a obecne w niej kanały pełnią funkcję prymitywnego układu krążenia transportującego zarówno substancje odżywcze, jak i produkty przemian metabolicznych. Bakterie w biofilmie posiadają zdolność komunikowania się przy użyciu sygnału chemicznego, który jest nośnikiem informacji rozpoznania liczebności, umożliwiającym uzyskanie odpowiedniej gęstości komórek bakteryjnych w biofilmie, co jest sygnałem do inwazji, czyli przerwania otoczki i uwolnienia komórek planktonowych. Biofilm jest oporny na mechanizmy obronne gospodarza, zaburza oczyszczanie śluzowo-rzęskowe, nie 
reaguje na odpowiedź komórkową i humoralną oraz na duże dawki antybiotyków niezależnie od czasu ich działania. Identyfikacja biofilmu bakteryjnego jest możliwa po pobraniu wycinków tkanki i ich ocenie w mikroskopie elektronowym. Najlepszą metodą jest badanie skrawków błony śluzowej gdo w Konfokalnym Skaningowym Mikroskopie Elektronowym, gdyż umożliwia jednoczesną ocenę struktury przestrzennej i identyfikację gatunku bakterii. Etiopatogeneza tworzenia biofilmu bakteryjnego jest wieloczynnikowa. Jedną z przyczyn jest antybiotykoterapia selekcjonująca bakterie pod względem genetycznym i metabolicznym. Drugą przyczyną tworzenia biofilmu jest dysfunkcja mechanicznych elementów chroniących błonę śluzową, tj. zahamowanie oczyszczania śluzowo-rzęskowego. Trzecią przyczyną są niedobory odporności. Biofilm to podstawowa forma życia bakterii i grzybów, drobnoustrojów saprofitycznych i chorobotwórczych, której nie znano dotychczas ze względu na brak możliwości diagnostycznych. Nie poznano dotychczas metod zachowawczych leczących zakażenia biofilmem, uważa się, że chirurgia jest skutecznym leczeniem chorób gardła, ucha i zatok przynosowych wywołanych zakażeniem biofilmem bakteryjnym i grzybiczym. Umożliwia usunięcie zakażonych tkanek, poprawia wentylację wymienionych okolic, co zapobiega i hamuje wzrost biofilmu.

\section{Wolfgang Pirsig}

Sesja rozpoczęcia

\section{Nasal physiology and the limits to nasal surgery in children}

\section{Department of Otorhinolaryngology, Head and Neck Surgery, Section for Rhinology and Rhonchopathies, University of Ulm, Germany}

The complex framework of the human nasal cartilages is the mobile portal to the respiratory system providing conditions for the passage of airstreams and the generation of nasal resistance and turbulence. The anterior nose with the nasal valve as its crucial functional region is the narrowest part of the upper airways and provides two thirds of the total airway resistance. The nasal resistance is highest in the newborn and continuously decreases with growth until the last quarter of the second decade. This means the comparison of measuring nasal resistance before septum or turbinate surgery, for instance, at the age of 6 and at follow-up 3 or 5 years later is of no proving value, because one cannot differentiate between the effects of natural history and of surgery. Together with the erectile lining of the nasal cavities the cartilaginous framework enables air-conditioning, defence, olfaction, and the acting of the nasal cycle. Many septum deviations are caused by midfacial injuries. But not each septum deviation is pathological. The incidence of the physiological septum deviation, characterized by a normal endonasal resistance, is reported between $30-75 \%$ for children. Many of these physiological septum deviations develop during the fetal life in connection with the asymmetric maxillary growth. The most effective outcome after functional rhinosurgery is achieved by focusing on restoring the physiologic functions of the anterior nose, the site of the most resistive nasal segment. However, there are essential anatomical differences between the growing and the adult nose. The nasal cartilages always heal incompletely. Internal stresses of the septum cartilage are endangered to result in shortening of the nose if vertical cuts or excisions are performed. The same holds true if the triangular cartilages are separated from the septum cartilage.

Also septum resection according to Killian or Freer is inhibiting nasal growth. The partial resection of the septum base connected to the anterior nasal spine will end in an underdevelopment of the maxilla. Radical reduction of the nasal turbinates may lead to nasal problems in adults, because it disturbs the nasal functions of air conditioning.

Wolfgang Pirsig Sesja VII

\section{Diagnostics and surgical treatment for children with obstructive sleep apnea}

Department of Otorhinolaryngology, Head and Neck Surgery, Section for Rhinology and Rhonchopathies, University of Ulm, Germany

We speak of obstructive sleep apnea (OSA) in children when the obstructive apnea index is equal or more than 1 per hour sleep. The ENT-doctor should search for OSA in children with obstructive T \&/or A, obesity, malocclusion, allergy and nasal pathology, laryngopharyngeal reflux, and craniofacilal malformations. As to symptoms there are differences between children and adults. A good diagnostic tool is the 'OSA - 18 - Quality of Life Survey'for children between 6 and 12 years. The often used pulsoximetry is depending on the quality of the pulseoximeter, and does often not record slight desaturations. Polysomnography is rarely performed in children. Mostly we can cure OSA by performing T \& A. All children with a pre-operative AHI $<10$ normalized after this surgery, while only $75 \%$ of children with AHI $>10$ normalized after surgery. Usually, in all children with persistent OSA caregivers reported snoring at 3-months follow-up. Therefore, if T \& A were without effect on OSA, excludeobesity,malocclusion, allergy, nose, and laryngopharyngeal reflux as reasons. There are no long-term results of treating turbinate hypertrophy with radio frequency for OSA in children. Rapid maxillary expansion is one treatment option for children with malocclusion and OSA. All the children with surgery because of OSA in early childhood should be controlled in the second decade when the development of occlusion is finished. 


\section{Wolfgang Pirsig}

Sesja VII

\section{Midfacial trauma in children: problems of diagnostic and proper treatment preventing further nasalfacial development}

Department of Otorhinolaryngology, Head and Neck Surgery, Section for Rhinology and Rhonchopathies, University of Ulm, Germany

The main problem is that sequelae of early untreated midfacial trauma appear after puberty to the full extent and that the long-term results of midfacial surgery depend on the time, size and locations of the acute nasal damages and are thus mostly not predictable. Diagnostic tools do not often give evidence, especially radiological imaging is reliable only in case of fractures of the nasal sinuses. Even an exploratory nasal surgery does often not provide the necessary information about the extent of midfacial damage. The septolateral cartilage forms a T-bar-shaped structure, is the dominating structure for nasal and midfacial growth and decisive for the appearance of the nose. Fractures or surgical cuts of this cartilage disturb the balanced system of its interlocked stresses. Furthermore, the incomplete healing of the cartilage and minor or major infections are reasons why rhinosurgery may inhibit the growing nose and the midface. Due to its protruding exposition the anterior nose is especially vulnerable to external injuries and may react as a protecting crumpled zone. This exposition also is the reason why most of the obstructing structures of the nasal airways are diagnosed in the anterior nose. Some rhinosurgical procedures may prevent damage to further nasalfacial development: hemitransfixion incision, mucoperichondrial tunnels, preservation of the septospinal ligament, resection of caudal rim of vomer in case of choanal atresia, avoidance of the complete posterior chondrotomy, avoiding the separation of the septum from the triangular cartilages, while osteotomies don't inhibit nasal growth. In case of septal abscess, the immediate treatment is recommended via hemitransfixion incision, removal of necrotic cartilage and granulation tissue, and immediate transplantation of autogenic ear cartilage. There are differences in the treatment of maxillary fractures in children and adults.

Beata Pucher, Jarosław Szydłowski, Michał Grzegorowski

Sesja VIII

\section{Technika EXIT (ex utero intrapartum treatment) - zastosowanie w przypadku niedrożności dróg oddechowych u płodu}

Katedra i Klinika Foniatrii i Audiologii Uniwersytetu
Medycznego im. K. Marcinkowskiego w Poznaniu

Niedrożność dróg oddechowych u noworodka związana jest $\mathrm{z}$ dużym odsetkiem umieralności w okresie okołoporodowym. Rozwój nowoczesnych technik obrazowania umożliwia diagnostykę malformacji głowy i szyi, zanim dziecko przyjdzie na świat. Wykrycie niedrożności dróg oddechowych przed urodzeniem stwarza możliwość zaplanowania postępowania mającego na celu zapewnienie noworodkowi drożności dróg oddechowych w trakcie porodu. Przy pomocy strategii EXIT (ex utero intrapartum treatment) możliwa jest ocena i zabezpieczenie drożności dróg oddechowych w trakcie akcji porodowej, ponieważ wykorzystuje się obecne nadal krążenie łożyskowo-płodowe, które zapewnia stały dopływ tlenu płodowi. Autorzy przedstawiają opisy przypadków zastosowania procedury EXIT w trakcie porodu $\mathrm{w}$ celu przywrócenia drożności dróg oddechowych u płodów z zespołem CHAOS agenezja lewego płuca.

Alicja Sekula Sesja IV

Obserwacja słuchu i rozwoju
komunikatywnego u dzieci z czynnikami
ryzyka w skryningu słuchowym
noworodków

Katedra i Klinika Foniatrii i Audiologii Uniwersytetu Medycznego im. K. Marcinkowskiego w Poznaniu

Konstrukcja programu badań przesiewowych słuchu u noworodków opiera się na ustaleniu w okresie noworodkowym czynników ryzyka wystąpienia wady słuchu oraz na pomiarze otoemisji wywołanej. Do dalszej diagnostyki audiologicznej kwalifikowane są noworodki, u których stwierdzono nieprawidłowy pomiar otoemisji w jednym lub obu uszach oraz po ustaleniu przynajmniej jednego czynnika ryzyka. Lista czynników ryzyka ewoluowała, aktualnie obowiązują ustalenia zawarte w protokole Programu. Ustalenie niedosłuchu odbiorczego na poziomie co najmniej $40 \mathrm{~dB}$ jest podstawą zaprotezowania, leczenia i wieloletniej rehabilitacji procesu komunikatywnego. Ustalenie, że dziecko mimo obecnych w wywiadzie czynników ryzyka słyszy na poziomie ustalonej normy, kończy obserwację dziecka w programie skryningu. Jednak niektóre czynniki ryzyka mogą w sposób progresywny ujawniać zaburzenia słuchu, więc przynajmniej do 3. roku życia prowadzona jest obserwacja pedoaudiologiczna dotycząca stanu słuchu i postępu rozwoju komunikatywnego.

Metodyka: W wybranym okresie trzech lat poddano obserwacji audiologiczno-foniatrycznej 300 dzieci z ustalonymi w Programie czynnikami ryzyka, u których w II etapie badania przesiewowego nie stwierdzono niedosłuchu odbiorczego.

Badania przeprowadzono zarówno ambulatoryjnie, jak i w ramach hospitalizacji. Dobór metody badania słuchu ustalano indywidualnie, w zależności od stanu przedmiotowego.

Wyniki: Podstawowa grupa dzieci, w której pojawił się niedosłuch oraz nieprawidłowy rozwój komunikatywny, to dzieci (27\%) ze skumulowanymi czynnikami określonymi jako okołoporodowe (wiek ciążowy, masa urodzeniowa, hyperbilirubinemia, Apgar, pobyt w inkubatorze, mechaniczna wentylacja) oraz noworodki z grupy TORCH. Nie potwierdzono podejrzenia o możliwość odległego pojawienia się niedosłuchu po stosowaniu leków ototoksycznych w okresie noworodkowym. 
Bożena Skotnicka

Sesja VIII

\section{Guzy naczyniowe głowy i szyi u dzieci}

\section{Klinika Otolaryngologii Dziecięcej Uniwersytetu Medycznego w Bialymstoku}

Guzy naczyniowe głowy i szyi obejmują swoim spektrum szereg zmian różniących się zarówno przebiegiem klinicznym, budową histologiczną, jak i markerami biologicznymi. Zgodnie z klasyfikacją Mullikena i Głowackiego (1982) wyróżniamy dwa główne typy zmian: naczyniaki i malformacje naczyniowe. Naczyniaki zazwyczaj nie są stwierdzane bezpośrednio po urodzeniu, pojawiają się w ciągu pierwszych tygodni życia, malformacje zawsze obecne sa od urodzenia. Naczyniaki wykazują szybką fazę proliferacji z następowym okresem wolnej inwolucji. Malformacje naczyniowe powiększają wraz z wiekiem, nie ulegają inwolucji. Naczyniaki dziecięce, najczęstsze guzy wieku dziecięcego, występują u ok. $12 \%$ populacji dzieci białych. Zmiany lokalizują się najczęściej (60\%) w obrębie głowy i szyi, 25\% w obrębie tułowia, 15\% w obrębie kończyn. Mają charakter zmian pojedynczych w $80 \%$, są mnogie w $20 \%$ (większe ryzyko naczyniaków trzewnych - wątroby, śledziony, płuc, mózgu, jelit). W zależności od położenia mogą być powierzchowne, głębokie lub mieszane oraz ograniczone lub segmentowe, zlokalizowane $\mathrm{w}$ okolicach odpowiadających segmentom rozwojowym twarzy. Zmiany ograniczone są 3-krotnie częstsze (76,3\%). Segmentowe wiążą się z wyższym ryzykiem towarzyszącym anomalii (zespół PHACE), zaburzeń funkcji i powikłań.

Wzrost naczyniaków odbywa się na zasadzie rozrostu, ze zwiększeniem ilości komórek endotelialnych i tucznych, obecnościa wielowarstwowej błony podstawnej. Guzy te są immunopozytywne w stosunku do markerów biologicznych: GLUT-1, Fc $\gamma$ RII, merozyna i Lewis Y antygen.

Faza proliferacji naczyniaków dziecięcych rozpoczyna się w pierwszych tygodniach życia i trwa przez 4-10 miesięcy. Naczyniaki głębokie (jamiste) mogą proliferować do 2. roku życia. Faza inwolucji trwa ponad 5-6 lat. 50\% naczyniaków dziecięcych cofa się do 5. rż., 90\% do 9. rż. W większości przypadków regresja guzów jest całkowita, jednakże $20-24 \%$ chorych wykazuje pozostałości zmian w postaci wiotkości skóry, przebarwień, teleangiektazji, ognisk zwłóknienia lub blizn.

1-2\% dzieci z naczyniakami skóry ma jednocześnie naczyniaki dróg oddechowych, głównie okolicy podgłośniowej. Współistnieją one najczęściej z naczyniakami zlokalizowanymi w obrębie brody i okolicy podbródkowej, linii żuchwy i okolicy przedusznej. Wymagają pilnej interwencji ze względu na możliwość obstrukcji dróg oddechowych.

Diagnostyka naczyniaków obejmuje wywiad, badanie przedmiotowe (także kardiologiczne i okulistyczne), ocenę przebiegu klinicznego, badania radiologiczne: USG z opcją Doppler, KT, NMR, angio- NMR, obrazowanie kardiologiczno-naczyniowe.

Leczenia wymaga ok. 12\% dzieci z naczyniakami, głównie $\mathrm{z}$ powodu obstrukcji dróg oddechowych, zaburzeń widzenia, zastoinowej niewydolności serca, owrzodzeń, krwawienia i trwałych deformacji. Obecnie (od 2008 r.) w leczeniu farmakologicznym stosuje się propranolol, doustny, nieselektywny beta bloker. Szacowany brak odpowiedzi na leczenie jest niski i wynosi ok. 1,6\%. Inne metody leczenia obejmują podawanie kortykosteroidów (systemowo, miejscowo), vinkrystyny, interferonu a $2 \mathrm{~A}$, laseroterapię oraz wycięcie chirurgiczne zmian.

Malformacje naczyniowe, rzadkie zmiany naczyniowe, złożone $\mathrm{z}$ różnych typów naczyń lub ich kombinacji, nie ulegają inwolucji, powiększają się wraz z wiekiem, często naciekają prawidłowe tkanki. Zaliczamy do nich naczyniaki limfatyczne, malformacje włośniczkowe (Port-winestain), żylne i tętniczo-żylne (szybkoprzepływowe). Diagnostyka zmian obejmuje ocenę przebiegu klinicznego oraz badania radiologiczne (USG, TK, NMR, angio-NMR). Stosowane leczenie w zależności od rodzaju zmiany to usunięcie chirurgiczne, laseroterapia (laser $\mathrm{CO}_{2}, \mathrm{KTP}, \mathrm{PDL}, \mathrm{Nd}$ : YAG), skleroterapia, embolizacja lub ich kombinacje.

\section{Sven-Eric Stangerup}

Sesja I

\section{Secretory otitis media and changes of the eardrum}

\section{ENT-Department Gentofte University Hospital, Kopenhaga,} Dania

Introduction: The significance of the Eustachian tube function in the pathogenesis of SOM and chronic middle ear disease has been discussed for many years. In many long term cohort studies it has been shown that $80 \%$ of all children suffers from SOM for some period of time before school age, whereafter the middle ear pressure improves with increasing age.

The aim of this presentation is to describe the tympanometric profile through childhood, and to relate these findings with the ocurrence, progression and prevalence of eardrum changes.

Material and methods: Three cohorts of children born in 1976, 1977 and 1979 were followed from age 0, 2 years and 4 years respectively until age 10 years at annual examinations and called in for a final reexamination at age 25 years. At all the examinations, otomicroscopy, audiometry and tympanometry were performed. For comparison a series of 498 children treated with ventilation tubes during the period 1967 to 1975 were reexamined 10 to 16 years after the initial treatment.

Conclusion: There was a high point prevalence of SOM from age 2 years to age 5 years. From age 6 years the middle ear condition gradually improved. We found a high significant correlation, between the duration of SOM and development of ear drum pathology, such as attic retractions, atrophy, atelectasis, adhesive otitis and myringosclerosis. Despite the tympanometric improvement, the prevalence of eardrum pathology increased to its maximum at age 16 years. The reason for this paradox might be that the eardrum pathology is easier to detect when 
the middle ear pressure is normalized and the retraction or effusion is normalized.

Jarosław Szydłowski

Sesja XIV

\section{Nawracająca brodawczakowatość układu oddechowego u dzieci - aktualna wiedza i możliwości leczenia}

Klinika Otolaryngologii Dziecięcej Katedry Otolaryngologii Uniwersytetu Medycznego im. K. Marcinkowskiego w Poznaniu

Nawracająca brodawczakowatość układu oddechowego jest najczęstszą niezłośliwą chorobą nowotworową dróg oddechowych u dzieci. Stanowi drugą co do częstości przyczynę chrypki w populacji wieku rozwojowego. Może mieć charakter łagodny $\mathrm{z}$ tendencją do samoograniczania lub przybrać postać agresywną cechującą się niekorzystnym rokowaniem. Proces chorobowy wpływa negatywnie na jakość życia chorego.

Materiały publikowane w latach 1970-1990 wskazywały współczynnik zachorowalności na poziomie $0,6-4,3$ nowych przypadków stwierdzanych każdego roku na 100 tysięcy dzieci. Parametr ten był wyraźnie niższy w Europie w stosunku do innych kontynentów. Zbierane wówczas dane opierały się na formie sprawozdań dostarczanych przez poszczególnych laryngologów lub kliniki laryngologiczne w postaci bezwzględnych wartości liczbowych. Obecnie jego wartość w Europie obniżyła się do 0,24 w 2009 roku. Obserwuje się jednak duże zróżnicowanie geograficzne. W tym samym okresie średni współczynnik zachorowalności w USA wynosił 0,73 i wahał się dla poszczególnych stanów w granicach 0,12 do 2,13. Badania prowadzone od lat 70. XX wieku pozwoliły na jednoznaczne określenie grupy niskoonkogennych wirusów brodawczaka ludzkiego jako czynnika etiologicznego rozwoju choroby.

Autor przedstawia współczesny stan wiedzy na temat przebiegu i możliwości leczenia tej niezwykle frustrującej jednostki chorobowej. Omawia własne doświadczenia dotyczące oceny mechanizmów swoistej i nieswoistej odpowiedzi immunologicznej oraz możliwości ich wykorzystania dla monitorowania i ewentualnego prognozowania przebiegu choroby u dzieci.

Jarosław Szydłowski,

Jagoda Kolasińska-Lipińska,

Beata Pucher,

Magdalena Prauzińska

Sesja XVII

\section{Zastosowanie plastyki balonowej w leczeniu długoodcinkowych zwężeń tchawicy}

Klinika Otolaryngologii Dziecięcej Katedry Otolaryngologii Uniwersytetu Medycznego im. K. Marcinkowskiego w Poznaniu

Długoodcinkowe zwężenia tchawicy u dzieci stanowią niezwykle trudny problem kliniczny z uwagi na zazwyczaj ciężki stan ogólny chorego dziecka oraz niewielką średnicę światła dróg oddechowych. Niezwykła rzadkość występowania tego problemu klinicznego sprawia, że nie opracowano dotychczas jednoznacznych zaleceń terapeutycznych, a postępowanie ma charakter zindywidualizowany.

Opisywane metody leczenia chirurgicznego przedstawiają resekcję zwężonego odcinka, tracheoplastyki typu „sidle" lub z zastosowaniem przeszczepu chrząstki żebrowej, przeszczepu okostnej czy osierdzia. Wykorzystuje się dostęp przedni przez rozszczepienie tchawicy lub dostęp tylny od strony ściany przełykowej.

Dla zapewnienia natlenowania organizmu procedury chirurgiczne realizuje się z wykorzystaniem krążenia pozaustrojowego lub ECMO.

Autorzy przedstawiają doświadczenia własne z wykorzystaniem techniki tracheoplastyki balonowej przy wykorzystaniu spontanicznej wentylacji do leczenia starannie wyselekcjonowanych przypadków długoodcinkowych zwężeń tchawicy. W okresie od września 2010 roku do października 2012 roku w Klinice Otolaryngologii Dziecięcej U.M. w Poznaniu leczono troje dzieci (dwoje niemowląt i 9-letniego chłopca) ze zwężeniem tchawicy ograniczającym jej światło na poziomie 70-90\% obejmującym od 50 do $70 \%$ długości tchawicy. W modelowaniu zwężeń tchawicy wykorzystano balony wysokociśnieniowe, a miejscowe działanie uzupełniono powierzchniową aplikacją mitomycyny $\mathrm{C}$ oraz $\mathrm{w}$ jednym przypadku śródściennym podaniem glikokortykoidu.

We wszystkich przypadkach w trakcie leczenia uzyskano satysfakcjonującą poprawę drożności światła tchawicy zapewniającą całkowite ustąpienie zaburzeń oddechowych. W jednym przypadku konieczne było wykonanie tracheotomii przed wdrożeniem leczenia kardiochirurgicznego.

\section{Jarosław Szydłowski}

Sesja XVII

\section{Urazy krtani i tchawicy}

Klinika Otolaryngologii Dziecięcej Katedry Otolaryngologii Uniwersytetu Medycznego im. K. Marcinkowskiego w Poznaniu

Urazy krtani oraz zwężenie zlokalizowane w obrębie krtani stanowią jednoznacznie domenę laryngologów i mieszczą się w obszarze ich działań zabiegowych zarówno w zakresie technik chirurgii endoskopowej, jak i zabiegów resekcyjnych czy rekonstrukcyjnych. Urazy i zwężenia tchawicy leczone są zarówno ośrodkach laryngologicznych, jak i torakochirurgicznych. Umownie za linię podziału przyjmuje się granicę wejścia do klatki piersiowej na poziomie wcięcia szyjnego mostka. Postępowanie w tych przypadkach wymaga wsparcia dobrze wyszkolonego zespołu anestezjologicznego oraz zabezpieczenia opieki pooperacyjnej w ramach oddziału intensywnej terapii medycznej.

Szczególnym wyzwaniem jest postępowanie w urazach tchawicy. Uszkodzenia ściany tchawicy są zazwyczaj konsekwencją działań lekarskich. Mogą być następstwem traumatycznej intubacji, przedłużonego utrzymywania rurki intubacyjnej w drogach oddechowych, ucisku przez rurkę 
tracheotomijną na ścianę tchawicy bądź konsekwencją zabiegów endoskopowych na drogach oddechowych.

W zwężeniach tchawicy obowiązują schematy postępowania zbliżone do przyjętych dla patologii zlokalizowanych w obrębie krtani. W ich zaopatrywaniu wykorzystuje się zarówno techniki endoskopowe, jak i zabiegi resekcyjne czy rekonstrukcyjne.

Ostre urazy tchawicy prowadzące do perforacji jej ściany pociągają za sobą konsekwencje w postaci szybko narastającej odmy śródpiersiowej i podskórnej, niewydolności oddechowej oraz wtórnego zakażenia śródpiersia. Stanowią stan nagły w laryngologii i niosą ryzyko bezpośredniego zagrożenia życia chorego. Wymagają - jeśli to tylko możliwe - pierwotnego zaopatrzenia uszkodzonej ściany tchawicy lub szczególnego postępowania zachowawczego $\mathrm{w}$ ramach oddziału intensywnej terapii.

\section{Krystyna Wąsowska-Królikowska}

Sesja II

\section{Wstrząs anafilaktyczny}

Klinika Alergologii, Gastroenterologii i Żywienia Dzieci Uniwersytetu Medycznego $w$ Łodzi

Wstrząs anafilaktyczny jest najcięższą postacią anafilaksji. Wynika z szybkiego przemieszczenia się dużych objętości płynu z łożyska naczyniowego do skóry, tkanki podskórnej i przestrzeni wewnątrzbrzusznej. Potencjalnie może być efektem każdej reakcji alergicznej.

Anafilaksja jest to ciężka, zagrażająca życiu, systemowa lub uogólniona natychmiastowa reakcja nadwrażliwości na powtórny kontakt z czynnikiem, który uprzednio był dobrze tolerowany. Objawy mogą być łagodne, umiarkowane lub ciężkie i choć $\mathrm{w}$ wielu przypadkach występują tylko objawy o niewielkim nasileniu, zawsze należy traktować anafilaksję jako stan zagrożenia życia. Anafilaksja wymaga szybkiego rozpoznania objawów, agresywnego leczenia oraz, jeśli to możliwe, jak najszybszego rozpoznania i eliminacji czynników wyzwalających. Właściwe rozpoznanie może nastręczać trudności, szczególnie u niemowląt i małych dzieci. Według WAO anafilaksja jest wysoce prawdopodobna przy wystąpieniu przynajmniej 1 z 3 następujących kryteriów:

1) szybkie pojawienie się (kilka minut do kilku godzin) objawów skórnych lub z błon śluzowych (nos, jama ustna, drogi oddechowe, przewód pokarmowy) skojarzonych z przynajmniej jednym z następujących:

- trudności z oddychaniem (duszność, świsty, stridor, hypoxia),

- spadek ciśnienia krwi;

2) dwa lub więcej z poniższych objawów pojawiających się wkrótce po ekspozycji na prawdopodobny alergen: - objawy skórne lub z błon śluzowych,

- problemy z oddychaniem, spadek ciśnienia krwi,

- utrzymujące się objawy z przewodu pokarmowego (skurcze w jamie brzusznej, wymioty);

3) spadek ciśnienia skurczowego krwi bezpośrednio po ekspozycji na znany alergen (minuty do kilku godzin): - 1 mies. - 1 rż. $\leq 70$ mm Hg (ciśnienie skurczowe),
- 1 rż. -10 rż. $\leq 70 \mathrm{~mm} \mathrm{Hg}+[2 \times$ wiek $]$,

- 11 rż - 17 rż. $\leq 90 \mathrm{~mm} \mathrm{Hg.}$

Prawdziwa częstość anafilaksji nie jest znana. Tym niemniej uważa się, że nie jest rzadka, a w dodatku obserwuje się narastający trend jej występowania. Najistotniejszym czynnikiem anafilaksji u dzieci, młodzieży i młodych dorosłych są alergeny pokarmowe (odpowiedzialne za 33,2-56\% reakcji anafilaktycznych), podczas gdy u osób w średnim wieku i starszych - leki $(13,7 \%)$ i owady żądlące $(18,5 \%)$. W ok. 20-30\% przypadków występuje anafilaksja idiopatyczna, której rozpoznanie opiera się na wywiadzie i wykluczeniu wpływu czynników zewnętrznych. Na szczególną uwagę zasługuje zjawisko anafilaksji wywoływanej wysiłkiem fizycznym po posiłku (FDEIA - Food-dependent exercise-induced anaphylaxis). Objawy mogą być ograniczone do jednego narządu lub układu albo mają charakter wielonarządowy, obejmując: skórę, śluzówki, górne i dolne drogi oddechowe, przewód pokarmowy, układ krążenia, układ nerwowy. W leczeniu anafilaksji najważniejsze znaczenie ma: adrenalina stosowana domięśniowo oraz odpowiednie ułożenie, tlen, płyny iv, beta2mimetyki, sterydy, H1 blokery. Bezwzględne wskazania do zapisania recepty na autostrzykawkę z adrenaliną obejmują: wcześniejszą reakcję sercowo-naczyniową lub oddechową na pokarm, ukłucie owada lub lateks; anafilaksję wysiłkową lub idiopatyczną oraz astmę współistniejącą z alergią pokarmową.

\section{Bożena Wiskirska-Woźnica} Sesja IV

\section{Uwagi do zaburzeń przetwarzania słuchowego u dzieci}

Katedra i Klinika Foniatrii i Audiologii Uniwersytetu
Medycznego im. Karola Marcinkowskiego w Poznaniu

(Centralne) Zaburzenia Przetwarzania Słuchowego (Central) Auditory Processing Disorders - (C)APD) jako jednostka chorobowa zostały zdefiniowane przez ekspertów American Speech, Language and Hearing Association (ASHA) dopiero pod koniec lat 90. Określa się je jako trudności w rozumieniu przekazu akustycznego przy prawidłowym jego odbiorze w strukturach obwodowych słyszenia. Powstają w wyniku zaburzeń funkcjonowania ośrodkowej części układu słuchowego, często na skutek niedotlenienia mózgu w czasie porodu, zapalenia opon mózgowych, urazów głowy, zatruć w dzieciństwie, ale też w wyniku braku właściwej stymulacji układu słuchowego we wczesnym dzieciństwie na tle zaniedbań wychowawczych. Zaburzenie to polega na niemożności efektywnego wykorzystania informacji słuchowo-językowej oraz błędnej interpretacji wrażeń słuchowych w wyniku upośledzenia uwagi, pamięci, percepcji i dyskryminacji słuchowej przy nieupośledzonej podstawowej funkcji słyszenia. Czermak i Musiek (1997) stwierdzili, że u ponad połowy dzieci, u których obserwuje się zaburzenia w procesie uczenia, dysleksję, zaburzenia uwagi z nadpobudliwością, można rozpoznać cechy zaburzenia przetwarzania słuchowego. Rutynowe badania psychofizyczne, audiometryczne nie są w stanie wykryć tego typu zaburzeń. Diagnostyka wymaga oceny interdyscyplinarnej polegającej na wykonaniu badań behawioralnych funkcji słuchowych (psycholog, pedagog), 
testów mowy „utrudnionej” tj. bardziej czułej wersji audiometrii mowy oraz badań elektrofizjologicznych ABR i potencjałów kognitywnych, głównie P300. W postępowaniu zaleca się zastosowanie technik kompensacyjnych umożliwiających pokonanie istniejących trudności w realizacji informacji słuchowych, trening słuchowy oraz interaktywne ćwiczenia $\mathrm{z}$ wykorzystaniem komputera i programów multimedialnych.

Anna Zakrzewska

Sesja II

\section{Problemy rozpoznawania chorób alergicznych u dzieci}

\section{Klinika Otolaryngologii Audiologii i Foniatrii Dziecięcej Uniwersytetu Medycznego $w$ Łodzi}

Jak istotnym problemem zdrowotnym są choroby alergiczne, najlepiej odzwierciedlają statystyki, albowiem około $40 \%$ dzieci choruje na alergiczny nieżyt nosa, atopowe zapalenie skóry i astmę, a prawie u 8\% stwierdza się alergię pokarmową.

Wyjaśniając patogenezę chorób alergicznych, obecnie wiemy, że rozwój choroby uwarunkowany jest wielogenowo, a wrodzoną skłonność do jej rozwoju warunkują polimorfizmy genów. Stymulacja antygenami środowiskowymi u osób predysponowanych prowadzi do rozwoju atopii, ekspozycja na swoiste antygeny prowadzi do uczulenia, a następne ekspozycje wywołują reakcję alergiczną.

Alergia jest to reakcja nadwrażliwości zapoczątkowana przez mechanizmy immunologiczne, najczęściej związane z przeciwciałami IgE. Rozpoznanie choroby alergicznej oparte jest na ustaleniu związku przyczynowego ekspozycji na alergen z objawami na podstawie których określa się rodzaj choroby. Oznacza to, że oprócz badania przedmiotowego i podmiotowego konieczne jest stosowanie standardów diagnostycznych, do których należą: testy skórne, oznaczanie całkowitego i alergenowo swoistego IgE w surowicy oraz testy prowokacyjne.

Wytyczne dotyczące rozpoznawania i leczenia alergicznego nieżytu nosa opracowywane są od 2001 roku w stale aktualizowanym dokumencie o nazwie ARIA (allergyrhinitis and itsimpact of astma), który obecnie obejmuje także zalecenia dotyczące współistniejącej astmy oskrzelowej. Alergiczny nieżyt nosa i spojówek rozpoznawany jest na podstawie objawów takich jak: kichanie, wyciek wodnistej wydzieliny, świąd, obturacja nosa, trwających powyżej godzinę dziennie poza okresem infekcji wirusowej oraz potwierdzenia tych objawów obecnością swoistych IgE. Przeprowadzone w 2003 roku badanie ECAP (Epidemiology of allergy and astma in Poland) pozwoliły na ustalenie, że objawy alergicznego nieżytu nosa w Polsce ma 25\% dzieci, zwiększając 4-8 krotnie ryzyko wystąpienia i zaostrzenia astmy. Natomiast znaczenie alergicznego nieżytu nosa dla rozwoju przewlekłego zapalenia zatok u dzieci podkreśla dokument EPOS 2012.

Alergia pokarmowa dotyczy już często najmłodszych dzieci. U niemowląt i dzieci młodszych $\mathrm{z}$ atopowym zapaleniem skóry, które mogą mieć alergię pokarmową, ekspozycja pogarsza przebieg choroby. W diagnostyce obowiązuje zasada, że w przypadku dodatnich testów skórnych i z krwi konieczne jest potwierdzenie dietą eliminacyjną, a w okresie późniejszym próba prowokacyjna z pokarmem podejrzewanym o wywołanie objawów.

Anafilaksja charakteryzuje się nagłymi objawami (uwidaczniającymi się w czasie minut) takimi jak: zaczerwienie, pokrzywka, obrzęk tkanki podskórnej oraz objawy ze strony układu oddechowego (podrażnienie, duszność: stridor, obturacja) i/lub krążenia (spadek RR, utrata świadomości). W ostatnich latach największy wzrost hospitalizacji z powodu anafilaksji dotyczy dzieci do 14 rż. (najczęściej do 4 rż.).

Zespół anafilaksji miejscowej jamy ustnej (OAS) polega na pojawieniu się świądu i obrzęku błony śluzowej warg, jamy ustnej, gardła oraz krtani kilka minut po spożyciu uczulającego pokarmu. Typowym obrazem jest zespół objawów występujących u osób chorujących na pyłkowicę po spożyciu świeżych owoców i warzyw, a reakcja krzyżowa spowodowana jest podobieństwem alergenów pokarmu i pyłków roślin.

Lidia Zawadzka-Głos

Sesja XVII

\section{Wady wrodzone nosa}

Klinika Otolaryngologii Dziecięcej Warszawskiego Uniwersytetu Medycznego

Patogeneza wad wrodzonych nosa jest nadal niejasna, ponieważ do zaburzeń rozwoju dochodzi w okresie wczesnej embriogenezy, tzn. między 4-12 tygodniem ciąży. Pod względem objawów klinicznych malformacje tego regionu można podzielić na dwie kategorie - wady wrodzone przebiegające z obturacją nosa i wady, w których drożność nosa jest prawidłowa. Głównym problemem dla chirurgii wad wrodzonych nosa i środkowej linii twarzoczaszki jest możliwość komunikacji wewnątrzczaszkowej z OUN. Dolegliwości kliniczne mogą być różne, począwszy od niewielkich zmian w wyglądzie, aż do poważnych, zagrażających życiu zaburzeń oddechowych.

Wady wrodzone nosa możemy pogrupować następująco: 1) wady w obrębie nozdrzy tylnych,

2) wrodzone torbiele grzbietu nosa, glioma, encephalocele,

3) wrodzone zwężenie otworu gruszkowatego,

4) inne, bardziej złożone malformacje.

Najczęstszą wadą wrodzoną jest niewykształcenie nozdrzy tylnych. Może być jednostronne lub obustronne, często współistnieje z innymi wadami. Niewykształcenie nozdrzy tylnych łącznie z innymi określonymi anomaliami jest kryterium diagnostycznym w zespole CHARGE i VATER. Rozpoznawane jest również w trisomii chromosomu 18 i 21, zespołach Di George'a, Aperta, Cruzona, Treachera-Collinsa i zespole Frynsa. Niewykształcenie nozdrzy tylnych w zespole CHARGE często wiąże się $\mathrm{z}$ medializacją kości skrzydłowej i operacyjne poszerzenie nozdrzy może okazać się trudne. 
Zwężenie nozdrzy przednich (CNPAS) jest rezultatem przedwczesnego połączenia i nadmiernego wzrostu środkowych wyrostków nosowych w czasie embriogenezy. W zaawansowanych przypadkach obraz kliniczny podobny jest do atrezji obustronnej nozdrzy tylnych u noworodków. Często współistnieje z innymi anomaliami, w tym dotyczącymi osi przysadkowo-nadnerczowej.

Wady w linii środkowej twarzoczaszki wymagają różnicowania pomiędzy torbielą grzbietu nosa, glioma lub encephalocele. Inne, bardziej złożone malformacje dotyczą dysplazji czołowo-nosowej i podlegają złożonemu wielospecjalistycznemu leczeniu.

\section{Lidia Zawadzka-Głos}

Sesja XVII

\section{Chirurgia endoskopowa krtani - możliwości i ograniczenia}

Klinika Otolaryngologii Dziecięcej Warszawskiego Uniwersytetu Medycznego

Chirurgia endoskopowa krtani jest jedną z technik operacyjnych leczenia nabytych i wrodzonych zmian w krtani. Obecnie obserwuje się wzrost popularności metod endoskopowego leczenia zwężeń dróg oddechowych. Ten trend spowodowany jest intensywnym rozwojem technik chirurgii endoskopowej, wprowadzeniem nowych instrumentariów oraz stosowaniem dodatkowo farmaceutyków o działaniu miejscowym. Endoskopia dróg oddechowych jest złotym standardem postępowania w diagnostyce patologii krtani i często na jej podstawie podejmujemy decyzję co do możliwości leczenia endoskopowego lub wybrania technik chirurgii otwartej. Zastosowanie chirurgii endoskopowej w leczeniu chorób krtani jest ogromne, a możliwości techniczne różnorodne (m.in. mikrochirurgia klasyczna, chirurgia laserowa, stosowanie mikrodebridera, proste dylatacje, endoskopowe wprowadzanie stentów, techniki z zastosowanie plazmy argonowej). Chirurgia endoskopowa doskonale sprawdza sie w zabiegach usuwania zmian egzofitycznych, zabiegach w laryngomalacji oraz laterofiksacji lub chordektomii z/lub bez arytenoidektomii, operacjach wrodzonych płetw krtaniowych czy też usuwania torbieli krtani. Podejmuje się operacje endoskopowego zamknięcia rozszczepu tylnego krtani, poszerzenia okolicy podgłośniowej w zwężeniach pointubacyjnych. Bardzo często endoskopowe poszerzenie okolicy podgłośniowej u niemowląt jest alternatywną metodą dla chirurgii otwartej. Według niektórych autorów wczesne leczenie endoskopowe zwężeń pointubacyjnych krtani może zmienić naturalny przebeg gojenia powikłań pointubacyjnych i ograniczyć wskazania do późniejszych zabiegów rekonstrukcyjnych. Może być pierwszą metodą leczenia zwężeń oraz metodą z wyboru leczenia zwężeń wtórnych po operacjach rekonstrukcyjnych technikami otwartymi. Oczywiście chirurgia endoskopowa ma wiele ograniczeń i nie może zastąpić zabiegów metodą otwartą w sytuacjach, kiedy są wskazania do zastosowania technik otwartych.

\section{Referaty i plakaty}

Ireneusz Bielecki, Mariusz Cofała, Agata Gierlotka

\section{Sesja XV}

\section{Usznopochodne i zatokowopochodne powikłania wewnątrzczaszkowe}

Oddział Laryngologii Górnośląskiego Centrum Zdrowia Dziecka w Katowicach

Obecnie powikłania zapaleń ucha i zatok przynosowych są coraz rzadziej spotykane w związku z rozpowszechnieniem stosowania antybiotyków. Typowe objawy powikłań mogą być jednakże maskowane prze długo trwające, leczone antybiotykami infekcje. Takie przypadki mogą stanowić duży problem diagnostyczny.

Materiał i metody: Retrospektywną analizę przeprowadzono na podstawie historii choroby dzieci leczonych w latach 2004-2012 w Oddziale Laryngologii Górnośląskiego Centrum Zdrowia Dziecka w Katowicach, z powodu uszno- i zatokowopochodnych powikłań wewnątrzczaszkowych. W pracy oceniono następujące parametry: wiek, płeć, źródło infekcji, rodzaj powikłania, wynik badania obrazowego, posiewy, leczenie chirurgiczne i farmakologiczne, czas trwania hospitalizacji oraz pochorobowe ubytki neurologiczne. Analiza obejmuje 32 dzieci: U 20 rozpoznano usznopochodne powikłania wewnątrzczaszkowe, a u 12 - zatokowopochodne.

Wyniki: Najczęściej występującym powikłaniem wśród dzieci z zapaleniem zatok przynosowych było zapalenie opon mózgowo-rdzeniowych i ropniak podtwardówkowy. W grupie powikłań zatokowopochodnych najczęściej stwierdzano zakrzepowe zapalenie zatok żylnych mózgu i zapalenie opon mózgowo-rdzeniowych. W leczeniu farmakologicznym w większości przypadków stosowano ceftriakson $\mathrm{z}$ wankomycyną, a także $\mathrm{w}$ wybranych przypadkach metronidazol dożylnie. Po ustaleniu rozpoznania powikłania wszystkie dzieci były leczone operacyjnie w trybie pilnym. Dodatkowo 4 pacjentów wymagało interwencji neurochirurgicznej. 1 pacjent zmarł. U 23 chorych stwierdzono całkowitą remisję bez ubytków neurologicznych, a 8 dzieci wymagało dalszej rehabilitacji neurologicznej. Postęp w technikach chirurgicznych i wczesne podjęcie decyzji o leczeniu operacyjnym znacząco obniżają śmiertelność w przypadkach zatokowopochodnych i uszno pochodnych powikłań wewnątrzczaszkowych.

\section{Lechosław Paweł Chmielik}

\section{Sesja IX}

\section{Uraz nosa u dziecka}

Klinika Otolaryngologii Dziecięcej Warszawskiego Uniwersytetu Medycznego

Wstęp: Dzieci ulęgają często urazom. Urazy u dzieci mogą występować w okresie prenatalnym, okołoporodowym i postnatalnym. Ich mechanizm może być prosty jak 
i złożony. Nos jako integralna część głowy ulega u dzieci dość częstym urazom. Należy pamiętać o tym, że uraz nosa często wiąże się z urazem głowy. Skutki urazu nosa, wczesne, jak i późne występują pod rozmaitymi postaciami. Istotne jest zaopatrzenie urazu w sposób właściwy. Dzięki właściwemu postępowaniu w okresie następującym bezpośrednio po wypadku możliwe jest skrócenie okresu rekonwalescencji i uniknięcie późnych następstw urazu.

Metoda: W pracy przedstawiono przegląd literatury oraz doświadczenia własne dotyczące urazów nosa u dzieci.

Materiał: Przeanalizowano 100 pacjentów leczonych z powodu złamania kości nosa w Klinice Otolaryngologii Warszawskiego Uniwersytetu Medycznego w latach 2011-2013.

Wnioski: 1) repozycja nosa jest skuteczną metodą leczenia następstw urazów nosa, jeśli jest stosowana w odpowiednim czasie po urazie, 2) repozycja kości nosa u dziecka powinna by zazwyczaj wykonywana w znieczuleniu ogólnym, 3) materiał opatrunkowy wewnątrznosowy nie powinien mieć właściwości rozprężających, 4) założenie tamponady do nosa u małego dziecka może prowadzić do zaburzenia funkcji życiowych i z tego względu takie dziecko wymaga monitorowania czynności życiowych w okresie pooperacyjnym.

Dorota Czech, Małgorzata Malicka, Ewa Kott, Janusz Konopacki, Anna Zakrzewska

\section{Sesja X}

\section{Zaburzenia artykulacji u dzieci przed rozpoczęciem nauki szkolnej jako objaw wymagający szczegółowej diagnostyki laryngologicznej}

\author{
Klinika Otolaryngologii Audiologii i Foniatrii Dziecięcej \\ Uniwersytetu Medycznego w Łodzi
}

Wstęp: Problem zaburzeń artykulacji u dzieci przedszkolnych nabiera znaczenia w związku z obniżeniem wieku rozpoczęcia spełniania obowiązku szkolnego. Nieprawidłowości artykulacji zaopatrywane są przez logopedów bez poprzedzającej takie działania diagnostyki lekarskiej.

Cel pracy: Celem pracy jest ocena częstości występowania zaburzeń artykulacji oraz próba ustalenia ich związku z problemami zdrowotnymi w zakresie chorób laryngologicznych u dzieci.

Materiał i metody: Przeprowadzono badanie epidemiologiczne oceniające mowę dzieci z losowo wybranych przedszkoli na terenie miasta Łodzi. Badanie zostało przeprowadzone wspólnie przez logopedę i laryngologa. Wybrana grupa dzieci z zaburzeniami artykulacji poddana była dalszej ocenie. Badanie obejmowało szczegółową ankietę dotyczącą rozwoju dziecka, wcześniejszych i obecnych dolegliwości; badaniem przedmiotowym oceniono ogólny stan zdrowia, przeprowadzono szczegółowe badanie laryngologiczne, łącznie z oceną stanu słuchu.
Wyniki: Zaburzenia wymowy wystąpiły u $42 \%$ badanych dzieci. Nieprawidłowości stwierdzone w badaniu laryngologicznym dotyczyły przede wszystkim zaburzeń drożności nosa wynikających ze zmian w obrębie nosa i nosogardła, a zmiany stwierdzone w otoskopii wskazywały na zaburzenia drożności trąbek słuchowych. Badania audiometryczne wykazały obecność niedosłuchu przewodzeniowego u $68 \%$ badanych dzieci. Badania tympanometryczne wskazywały na nieprawidłowości o charakterze zaburzeń wydolności trąbek słuchowych, jedynie w pojedynczych przypadkach (troje dzieci) na obecność płynu w jamie bębenkowej. Niedosłuch przewodzeniowy okazał się najczęściej współistniejącym z dyslalią problemem laryngologicznym. Czynnikami, których istotność potwierdzono statystycznie, współistniejącymi z zaburzeniami artykulacji, był niedosłuch przewodzeniowy lekkiego stopnia oraz zaburzenia drożności nosa.

Wnioski: 1) W przypadku stwierdzenia zaburzeń artykulacji konieczna jest dokładna diagnostyka laryngologiczna oraz ocena stanu słuchu. 2) Niedosłuch przewodzeniowy lekkiego stopnia jest najczęstszym problemem zdrowotnym u dzieci z zaburzeniami wymowy. 3) Niedosłuch przewodzeniowy u dzieci z zaburzeniami artykulacji związany był z niewydolnością trąbek słuchowych, a nie obecnością płynu w jamach bębenkowych.

Monika Jabłońska-Jesionowska, Lidia Zawadzka-Głos Sesja IX

\section{Pierścień naczyniowy przyczyną wrodzonego stridoru oddechowego}

Klinika Otolaryngologii Dziecięcej Warszawskiego Uniwersytetu Medycznego

Wrodzony stridor oddechowy u dzieci spowodowany nieprawidłowym przebiegiem naczyń tętniczych występuje rzadko. Ze względu na skąpość objawów pierścienie naczyniowe często rozpoznawane są przypadkowo. Jednym z objawów jest wrodzony stridor oddechowy, który zawsze wymaga diagnostyki. Celem pracy była analiza przyczyn wrodzonego stridoru oddechowego u dzieci, ze szczególnym uwzględnieniem anomalii naczyń tętniczych.

Przeanalizowano 116 dzieci hospitalizowanych w Klinice ORL Dziecięcej WUM w latach 2010-2013 z powodu wrodzonego stridoru oddechowego. U wszystkich dzieci wykonano RTG klatki piersiowej i przełyku z kontrastem, USG przezciemiączkowe i krtani, EKG, ECHO serca, laryngotracheoskopię. U części wykonano ANGIO CT.

Analiza danych potwierdziła wrodzony stridor oddechowy spowodowany anomalią naczyń tętniczych u 15 dzieci. Wrodzony stridor oddechowy zawsze wymaga diagnostyki. Nie każdy spowodowany jest patologią krtani lub tchawicy. Wrodzone anomalie naczyń tętniczych ze względu na interdyscyplinarny problem rozpoznawane są w różnym wieku dziecka. Diagnostyka powinna obejmować badania: laryngologiczne, neurologiczne, gastroenterologiczne i kardiologiczne. 
Marcin Kawalski

\section{Przydatność czasu przejścia fali tętna} w rozpoznawaniu zaburzeń oddychania w czasie snu u dzieci

Szpital im I. Mościckiego - Lecznica Dzieci i Dorosłych, Chorzów

Zaburzenia oddychania podczas snu u dzieci są zjawiskiem częstym, lecz relatywnie rzadko rozpoznawanym. Nieleczone prowadzą do szeregu istotnych konsekwencji, od chrapania pierwotnego po zespół bezdechów sennych $\mathrm{z}$ towarzyszącym upośledzeniem rozwoju intelektualnego i fizycznego.

Złotym standardem diagnostycznym jest pełne badanie polisomnograficzne, które jednakże obarczone jest cechami utrudniającymi powszechne stosowanie. Mała liczba laboratoriów snu dysponujących przeszkolonym personelem oraz wyposażonych w odpowiednią aparaturę, jej wysoki koszt czy czasochłonność badania to tylko niektóre z przyczyn stanowiących o ograniczonej dostępności polisomnografii. Poszukuje się czułych, swoistych i dostępnych ekonomicznie metod pozwalających na szybką identyfikację pacjentów z zaburzeniami oddychania.

Przedmiotem pracy była ocena przydatności czasu przejścia fali tętna w przesiewowej diagnostyce zaburzeń oddychania u dzieci. Metodę tą porównano z pulsoksymetrią nocną, oceną zmienności rytmu serca i oceną przebudzeń centralnych pod kątem identyfikacji pacjentów wymagających dalszej diagnostyki i leczenia.

Badanie obejmowało grupę 153 dzieci w wieku 3-14 lat, leczonych w Szpitalu im. I. Mościckiego w Chorzowie z powodu podejrzenia zaburzeń oddychania podczas snu. U wszystkich dzieci wykonano pełne badanie polisomnograficzne i oceniono zdolność prognozowania jego wyniku przez poszczególne metody.

Wyniki pomiarów czasu przejścia fali tętna okazały się bardzo silnie skorelowane $\mathrm{z}$ wartościami wskaźnika zaburzeń oddychania. Zarówno w poszczególnych grupach wiekowych, jak i u wszystkich pacjentów znaleziono istotną statystycznie zależność pomiędzy powyższymi parametrami.

Ocena czasu przejścia fali tętna okazała się skuteczniejszym narzędziem diagnostycznym niż pozostałe analizowane metody. Pomiar czasu przejścia fali tętna jest czułym wskaźnikiem obecności zaburzeń oddychania u dzieci, pozwala na zróżnicowanie typów zaburzeń oddychania oraz na identyfikację dyskretnych ograniczeń wentylacji. Jako metoda prosta i tania może znaleźć zastosowanie w przesiewowych badaniach zaburzeń oddychania u dzieci.
Maciej Kotecki, Danuta Gryczyńska Sesja XI

\section{Badania nad wpływem hałasu na stan słuchu młodzieży szkolnej}

\author{
Klinika Otolaryngologii Audiologii i Foniatrii Dziecięcej \\ Uniwersytetu Medycznego w Lodzi
}

Celem pracy jest ocena stanu słuchu u młodzieży szkolnej narażonej na dodatkowe źródła hałasu związane z nauką przyszłego zawodu lub realizacją przyjemności.

Materiał obejmuje 150 pacjentów w wieku od 15 do 18 lat, w tym: 55 uczniów szkoły zawodowej, 50 uczniów szkoły muzycznej i 45 nastolatków słuchających muzyki przez przenośne odtwarzacze muzyczne. Wyniki porównano $\mathrm{z}$ grupą kontrolną 200 uczniów liceów ogólnokształcących w analogicznym przedziale wiekowym, którzy nie byli narażeni na dodatkowe źródła hałasu.

Metody badań: U wszystkich pacjentów przeprowadzono następującą diagnostykę: wywiad, badanie otoskopowe, badanie audiometrii tonalnej progowej, z określeniem krzywej przewodnictwa kostnego i powietrznego.

Wyniki: Prawidłowe wyniki audiometryczne stwierdzono u pacjentów uczęszczających do szkoły muzycznej, podwyższenie krzywej progowej o charakterze uszkodzenia słuchu dla wysokich czestotliwości (o typie urazu akustycznego) stwierdzono u pacjentów słuchających muzyki przez przenośne odtwarzacze muzyczne (6 pacjentów) oraz u pacjentów ze szkoły zawodowej (15 pacjentów). W grupie kontrolnej wyniki audiometryczne były prawidłowe.

Wnioski: Młodzież narażona na dodatkowe źródła hałasu powinna być grupą szczególnej troski i mieć okresowe kontrole słuchu. Wczesne wykrycie ubytku słuchu wymaga okresowych audiometrycznych badań słuchu. Wskazane jest działanie profilaktyczne wśród młodzieży polegające na edukacji i stosowaniu ochronników słuchu oraz przestrzeganiu odpoczynku po narażeniu na hałas.

\section{Michał Kotowski, Grażyna Niedzielska Sesja XV}

\section{Guzy nosogardła u dzieci}

\section{Klinika Otolaryngologii Dziecięcej, Foniatrii i Audiologii} Uniwersytetu Medycznego w Lublinie

Guzy regionu głowy i szyi u dzieci zazwyczaj mają charakter łagodny. Jednakże nowotwory głowy i szyi to około 5\% wszystkich procesów złośliwych okresu rozwojowego. Niewielki odsetek tych zmian stanowią guzy nosogardła.

Celem pracy była analiza retrospektywna zmian prowadzących do zaburzeń drożności dróg oddechowych wymagających leczenia operacyjnego w Klinice Otolaryngologii Dziecięcej Foniatrii i Audiologii UM w Lublinie w latach 2003-2012.

Badaniami objęto 18 pacjentów w wieku od 1 tygodnia życia do 16,5 roku życia. W populacji 32788 dzieci, które 
zgłosiły się do Kliniki, 0,055\% zostało zdiagnozowanych jako zmiana rozrostowa nosogardła. U większości operowanych głównym objawem chorobowym była niedrożność nosa powodująca duszność.

W naszym materiale w większości operowanych guzów były to zmiany łagodne (10 przypadków). Guzy złośliwe w liczbie 8 dotyczyły w większości płci męskiej (7 przypadków). Wśród nowotworów złośliwych nosogardłarozpoznano rhabdomyosarcoma w 4 przypadkach oraz chłoniaki u 3 pacjentów. W grupie nowotworów niezłośliwych leczono pojedyncze przypadki guzów często dających wznowy, tj. Schneiderian papilloma, myxoma, chondromachonromyxoides.

Małgorzata Malicka, Jan Sokal, Anna Zakrzewska Sesja XV

\section{Ocena urazów nosa w ultrasonografii wysokoczęstotliwościowej - badanie pilotażowe}

\author{
Klinika Otolaryngologii Audiologii i Foniatrii Dziecięcej \\ Uniwersytetu Medycznego w Łodzi \\ Zakład Diagnostyki Obrazowej SP ZOZ USK nr 4 w Łodzi
}

Wieloletnie obserwacje jednoznacznie potwierdzają wpływ przebytych urazów nosa na rozwój twarzoczaszki. Bardzo ważnym aspektem diagnostycznym szczególnie w przypadku dzieci młodszych jest zastosowanie bezinwazyjnych metod badania oceniających rozległość i rodzaj uszkodzeń.

Cel pracy: Celem pracy była próba oceny zmian pourazowych nosa i twarzoczaszki ze szczególnym uwzględnieniem wysokich krwiaków przegrody i konieczności podjęcia decyzji o ich szybkim odbarczeniu u dzieci z masywnym obrzękiem pourazowym utrudniającym badanie.

Materiał i metody: Grupę badaną stanowiło 28 dzieci w wieku 1,5 rż. do 17. rż. Badania wykonywano aparatem iU22 marki Philips przy użyciu sondy liniowej $17 \mathrm{MHz}$ pozwalającej na ocenę powierzchownie położonych zmian. Równolegle wykonywano klasyczną ocenę rtg kości nosa w projekcji bocznej i TK w wybranych przypadkach.

Wyniki: Potwierdzono złamanie w 16 przypadkach, oceniono przemieszczenie odłamów. Współistniejący krwiak przegrody uwidoczniono w 6 przypadkach. Podjęto decyzję o odbarczeniu krwiaka w trybie pilnym. We wszystkich przypadkach w badaniu odległym po 6 mies. stwierdzono prawidłowy stan przegrody i jam nosa. W 8 przypadkach stwierdzono zmiany obrzękowe tkanek miękkich nosa i środkowej części twarzy bez cech krwiaka. U pozostałych pacjentów wykluczono zmiany pourazowe.

Wnioski: Poszerzenie grupy badanej pozwoli na odpowiedź na pytanie, czy można badaniem USG będącym metodą bezinwazyjną zastąpić badanie rtg w przypadkach urazów nosa u dzieci, a szczególnie u dzieci młodszych. W przedstawionych przypadkach potwierdzono skuteczność oceny USG w monitorowaniu pourazowych krwiaków przegrody nosa.

Grażyna Mielnik-Niedzielska, Piotr Żychowski Sesja IX

\title{
Ocena wyników leczenia operacyjnego niedrożności nozdrzy tylnych
}

\author{
Klinika Otolaryngologii Dziecięcej, Foniatrii i Audiologii \\ Uniwersytetu Medycznego w Lublinie
}

Niedrożność nozdrzy tylnych jest rzadkim zaburzeniem rozwojowym występującym raz na około 8000 żywo urodzonych noworodków. Obustronna wada ze względu na duszność wymaga leczenia w pierwszych dniach życia, natomiast udrożnienie niedrożności jednostronnej może być odłożone w czasie.

Celem pracy była retrospektywna ocena leczenia przypadków niewykształcenia nozdrzy tylnych leczonych operacyjnie w Klinice Otolaryngologii Dziecięcej, Foniatrii i Audiologii UM w Lublinie w latach 2003-2012. Dokonano analizy porównawczej miejscowego działania Mitomycyny $\mathrm{C}$ i stentowania w zapobieganiu bliznowaceniu i powstawaniu restenoz $\mathrm{w}$ okresie pooperacyjnym.

Analizie poddano 34 dzieci. Było to 24 dziewczynki $(70,6 \%)$ i 10 chłopców $(29,4 \%)$ w wieku od 6 dnia do 11 roku życia. Wszyscy pacjenci mieli przeprowadzoną operację przeznosową. U $22(64,7 \%)$ dzieci założono stenty wewnątrznosowe, u $9(26,5 \%)$ zastosowano Mitomycynę C, natomiast u pozostałych trojga $(8,8 \%)$ użyto stenty, a restenozy operowano $z$ użyciem Mitomycyny C. Reoperacji z powodu przewężenia światła choan wymagało 5 spośród 25 pacjentów (20\%), u których założono stenty. W 22 przypadkach ponownie zastosowano stentowanie, w 3 użyto mitomycyny c. Wśród dzieci leczonych bez stentowania, u których zastosowano Mitomycynę C, reoperacja konieczna była w 1 przypadku $(11,1 \%)$.

Mitomycyna C stosowana w zapobieganiu bliznowacenia tkanek jest godna polecenia. Oprócz skuteczności niewątpliwą zaletą miejscowego stosowania tego preparatu jest komfort opieki pooperacyjnej i duża akceptacja rodziców, często trudna do uzyskania w przypadku stentowania.

\section{Grażyna Mielnik-Niedzielska, Elżbieta Bielak-Cywińska, Kornela Patrycka-Pietrzyk}

\section{Sesja XI}

\section{Powikłania drenażu wentylacyjnego ucha środkowego u dzieci}

Klinika Otolaryngologii Dziecięcej, Foniatrii i Audiologii
Uniwersytetu Medycznego w Lublinie

Wstęp: Wysiękowe zapalenie ucha środkowego jest jedną z najczęściej rozpoznawanych jednostek chorobowych wieku dziecięcego.

Cel pracy: Celem pracy była ocena otologiczna oraz audiometryczna dzieci leczonych z powodu wysiękowego zapalenia ucha środkowego, u których wykonano drenaż wentylacyjny. 
Materiał i metody: W badaniu wzięło udział 75 dzieci (136 uszu) - 44\% pacjentów hospitalizowanych w latach 2006-2010 w tutejszej Klinice, u których wykonano myryngotomię z wszczepieniem drenażu wentylacyjnego do jamy bębenkowej z powodu OMS. Do analizy wykorzystano badanie videootoskopowe, badanie tympanometryczne $\mathrm{z}$ odruchem z mięśnia strzemiączkowego, badanie audiologiczne tonalne oraz DPOAE.

Wyniki: W 70 przebadanych uszach nie stwierdzono istotnych zmian wziernikowych. W 46,3\% badanych uszu występowały trwale zmiany strukturalne błony bębenkowej - najczęściej myryngoskleroza oraz kieszonki retrakcyjne. W 3 uszach obecność przetrwałej perforacji wymagała przeprowadzenia zabiegu myryngoplastyki.

Niedosłuch przewodzeniowy stwierdzono w 50 uszach, a 71 zaś słuch był prawidłowy. W 13 przypadkach nie wykonano badania audiometrii tonalnej ze względu na brak współpracy pacjenta.

Wnioski: Drenaż wentylacyjny prowadzi do zwiększenia występowania długoterminowych patologii błony bębenkowej. Najczęściej obserwowaną zmianą była myryngoskleroza. W okresie obserwacyjnym od 2 do 6 lat po zabiegu choroba była nadal obecna u części pacjentów. Myryngotomia z wszczepieniem drenażu wentylacyjnego do jamy bębenkowej jest metodą rekomendowaną, pomimo że nie zawsze daje satysfakcjonujący wynik leczenia.

\section{Artur Niedzielski, Tomasz Horoch \\ Mucocele jamy ustnej u pacjentów pediatrycznych} Sesja XI

\section{Klinika Otolaryngologii Dziecięcej, Foniatrii Audiologii} Dziecięcego Szpitala Klinicznego w Lublinie

Mucocele jest stosukowo często występującą zmianą w populacji ludzi dorosłych, natomiast rzadko występuje u dzieci. Jest to torbiel śluzowa gruczołu ślinowego, powstała na skutek niemożności odpływu wydzieliny. Dokładna etiologia nie jest znana, jednak do najczęstszych czynników wywołujących należą urazy, stany zapalne oraz niedrożność przewodów wyprowadzających.

Celem badania była ocena wyników leczenia chirurgicznego wyżej opisanej zmiany.

Mucocele rozpoznano u 33 pacjentów pediatrycznych Kliniki Otolaryngologii Dziecięcej w Lublinie leczonych w latach 2007-2013. Wszystkie przypadki zakwalifikowano do leczenia operacyjnego. Według danych z piśmiennictwa wiadomo, że najczęstszą lokalizacją mucocele była warga dolna. Dane z literatury również podają częstsze występowanie mucocele w tej lokalizacji u mężczyzn. W przypadku badanej grupy zmiana na wardze dolnej występowała w 23 przypadkach $(71,8 \%)$. W naszej grupie na wardze dolnej mucocele wystąpiło u 18 dziewczynek (72\%) i 7 chłopców (28\%). W pozostałych przypadkach zmiana zlokalizowana była na języku - 9 przypadków (27\%), w tym 4 przypadki były to dziewczynki (44\%), w 5 przypadkach zmiana wystąpiła u chłopców (56\%). Nie zaobserwowano żadnego nawrotu choroby po chirurgicznym usunięciu zmiany. Wycięcie zmiany wydaje się być ostatecznym postępowaniem w przypadku mucocele. Badanie histopatologiczne pozwala na różnicowanie mucocele $\mathrm{z}$ ziarniniakiem naczyniowym, który jest drugą co do częstości zmianą występującą w podobnej lokalizacji.

\section{Renata Pepaś, Małgorzata Śmiechura, Wiesław Konopka \\ Diagnostyka otoneurologiczna dzieci z zaburzeniami równowagi}

\section{Sesja XI}

Klinika Otolaryngologiczna Instytutu Centrum Zdrowia Matki Polki w Łodzi

Wstęp: Badanie otoneurologiczne małego dziecka, mimo że obejmuje podobne elementy jak u dorosłych, jest trudne. Istotne znaczenie dla dalszego postępowania ma ustalenie, czy występujące zawroty głowy mają charakter obwodowy czy ośrodkowy, a także czy występują inne dolegliwości, które mogą sugerować chorobę ogólnoustrojową lub zaburzenia czynnościowe.

Cel: Celem pracy była ocena sprawności układu przedsionkowego w wybranej grupie dzieci z zaburzeniami równowagi.

Materiał i metody: Badaniem objęto 20 chorych konsultowanych i diagnozowanych $\mathrm{z}$ powodu zaburzeń równowagi przez neurologa (11 dziewczynek i 9 chłopców), w wieku od 5 do 17 lat (średnio 14 lat $\pm 3,4$ ). U wszystkich wykonano badanie otolaryngologiczne oraz otoneurologiczne, diagnostykę audiologiczną. Badanie elektronystagmograficzne przeprowadzono u 12 pacjentów, a wideonystagmograficzne u 8 dzieci. Oceniano oczopląs samoistny, próby położeniowe, okoruchowe i próby kaloryczne $\mathrm{z}$ oceną przewagi kierunkowej i niedowładu kanałowego.

Wyniki: Prawidłowe próby statyczno-dynamiczne stwierdzono u 17 badanych, u 2 pacjentów wystąpiło padanie do tyłu, u 1 osoby niestabilność. Prawidłowy stan słuchu stwierdzono u 17 badanych, u 2 zarejestrowano głuchotę jednostronną, a u 1 wrodzoną obustronną. Uszkodzenie obwodowej części układu równowagi rozpoznano u 4 pacjentów, natomiast uszkodzenie typu ośrodkowego u 12 badanych, a u 1 osoby zaobserwowano całkowity brak pobudliwości błędników. U 3 osób nie udało się ukończyć badania nystagmograficznego (bardzo nasilone objawy wegetatywne, tuby wentylacyjne) lub były one niewiarygodne (przyjmowane leki).

Wnioski: W badanej grupie przewagę stanowiły zaburzenia równowagi pochodzenia innego niż obwodowe. Zarówno badanie elekronystagmograficzne, jak i wideostygmograficzne jest niezwykle cenne w ocenie lokalizacji uszkodzenia układu równowagi. Badanie wideonystagmograficzne w sposób bardziej precyzyjny pozwala na obserwację i rejestrację oczopląsu. 
Małgorzata Piszcz, Artur Goździewski Sesja XI

Torbiele dermoidalne głowy i szyi u dzieci - opisy przypadków

\author{
Klinika Otolaryngologii Dziecięcej Uniwersytetu Medycznego \\ $w$ Białymstoku
}

Torbiele dermoidalne (skórzaste) są łagodnymi guzami wrodzonymi, rzadko występującymi w rejonie głowy i szyi u dzieci. Należą do grupy anomalii rozwojowych multipotencjalnych komórek embrionalnych o nazwie teratomy, a wywodzą się z 2 listków zarodkowych: ekto- i mezodermy. Teratomy definiowane są jako nowotwory łagodne, których tkanka jest obca dla rejonu ciała ludzkiego, w którym guz ujawnia się klinicznie. Celem pracy była analiza częstości występowania torbieli dermoidalnych głowy i szyi oraz ich specyfiki u dzieci hospitalizowanych i operowanych w naszej Klinice w latach 1995-2013. Analiza materiału klinicznego obejmowała 29 przypadków i wykazała dominację lokalizacji tych guzów w okolicy podbródkowej. W pracy omówione zostaną wybrane przypadki z uwzględnieniem trudności w diagnostyce różnicowej, wynikających z lokalizacji tych zmian w linii pośrodkowej głowy i szyi, typowej dla innych łagodnych zmian rozwojowych. W celu właściwego rozpoznanie torbieli skórzastych w okresie przedoperacyjnym, bardzo pomocne jest badanie tomografii komputerowej, w której uzyskujemy charakterystyczny dla tych guzów obraz „szklanych kulek”. Właściwa diagnostyka radiologiczna może wpłynąć na zakres planowanego leczenia operacyjnego.

\section{Joanna Radzikowska, Wojciech Kukwa, Andrzej Kukwa, Piotr Wójtowicz, Antoni Krzeski} Sesja XV

\section{Guzy lite głowy i szyi u dzieci}

\section{Klinika Otolaryngologii Wydziału Lekarsko-Dentystycznego Warszawskiego Uniwersytetu Medycznego}

Przedstawiamy grupę 60 dzieci z guzami litymi w regionie głowy i szyi, które były leczone w Klinice Otolaryngologii Wydziału Lekarsko-Dentystycznego Warszawskiego Uniwersytetu Medycznego w latach 2000-2012. Wszystkie dzieci leczone były we współpracy z onkologami dziecięcymi z pediatrycznych ośrodków onkologicznych na terenie całego kraju. Była to grupa zróżnicowana pod względem lokalizacji i typu histopatologicznego guza. Ponad połowę pacjentów stanowiły dzieci z mięsakiem prążkowanokomórkowym. 46\% przypadków dotyczyło guzów naciekających więcej niż jeden region anatomiczny. Leczenie chirurgiczne stanowiło w większości przypadków element leczenia skojarzonego, połowa zabiegów operacyjnych dotyczyła wznowy procesu nowotworowego. Wysoki stopień zaawansowania klinicznego nowotworu, trudności w uzyskaniu radykalności resekcji zwłaszcza w regionie podstawy czaszki, operacje poprzedzone radioterapią oraz leczenie wznów stanowiły największe wyzwanie.

Wnioski: Postępowanie w przypadku guzów litych głowy i szyi u dzieci powinno być interdyscyplinarne od momentu rozpoznania. Każdy przypadek wymaga indywidualnego planowania leczenia we współpracy z onkologiem dziecięcym i rodzicami dziecka. Leczenie chirurgiczne guzów litych regionu głowy i szyi u dzieci jest wynikiem kompromisu między okaleczającą resekcją R0 a koniecznością skojarzonej terapii przy resekcji R1. Warunkiem doskonalenia protokołów leczenia jest raportowanie do centralnej bazy danych wyników terapii i jej powikłań.

\author{
Teresa Ryczer, Lidia Zawadzka-Głos, \\ Małgorzata Dębska, \\ Monika Jabłońska-Jesionowska
} Sesja IX

\section{Charakterystyka kliniczna pacjentów $\mathrm{w}$ wieku rozwojowym $\mathrm{z}$ podejrzeniem ciała obcego w drogach oddechowych} Klinika Otolaryngologii Dziecięcej Warszawskiego Uniwersytetu
Medycznego

Wstęp: Ciała obce w drogach oddechowych u dzieci stanowią ważny problem kliniczny. Ustalenie rozpoznania może powodować trudności ze względu na niespecyficzność objawów klinicznych oraz różnorodność opisywanych zmian osłuchowych i radiologicznych w zdjęciu rentgenowskim klatki piersiowej.

Celem pracy jest analiza kliniczna pacjentów z podejrzeniem ciała obcego w drogach oddechowych w Klinice Otolaryngologii Dziecięcej WUM w latach 2008-2012.

Materiał i metodyka: Oceniano m.in. wiek, płeć, objawy kliniczne, zmiany osłuchowe, zmiany w rentgenogramach klp, rodzaj ciała obcego. W latach 2008-2012 w Klinice hospitalizowano 67 dzieci $(M-45, K-22)$ z podejrzeniem ciała obcego w drogach oddechowych. Wszyscy pacjenci mieli wykonaną bronchoskopię.

Wyniki: U 56 dzieci stwierdzono ciało obce, którym najczęściej był orzeszek $(n=43) .60$ dzieci miało dodatni wywiad w kierunku zakrztuszenia. U 39\% dzieci występował kaszel. U 37\% asymetria szmeru pęcherzykowego. U 35\% opisywano nadmierne upowietrznienie płuc na zdjęciu rtg klp.

Wnioski: Diagnostyka w kierunku ciała obcego w drogach oddechowych wymaga dużej czujności klinicznej. Badanie pediatryczne, rtg klp AP oraz na boku poziomym promieniem mogą nie wskazywać jednoznacznie na obecność ciała obcego w drogach oddechowych. W każdym wypadku podejrzenia ciała obcego należy wykonać bronchoskopię, w szczególności kiedy wystąpił epizod zakrztuszenia $\mathrm{z}$ zasinieniem. 
Teresa Ryczer, Lidia Zawadzka-Głos, Małgorzata Dąbska, Monika Jabłońska-Jesionowska

\section{Powikłania wewnątrzskroniowe u dzieci z zapaleniem ucha środkowego}

Klinika Otolaryngologii Dziecięcej Warszawskiego Uniwersytetu Medycznego

Wstęp: Powikłania usznopochodne mogą wystąpić zarówno w ostrym, jak i przewlekłym zapaleniu ucha środkowego. Mimo rozpowszechnionej antybiotykoterapii nadal są często spotykane w praktyce klinicznej, w szczególności w populacji dziecięcej.

Materiał i metodyka: Analizą objęto pacjentów hospitalizowanych w Klinice Dziecięcej ORL WUM z powodu powikłań usznopochodnych w okresie styczeń 2011 - styczeń 2013. Oceniano m.in. dane demograficzne pacjentów, rodzaj powikłań, postępowanie.

Wyniki: Hospitalizowano 24 dzieci z powikłaniami usznopochodnymi $(\mathrm{M}=14, \mathrm{~K}=10)$, mediana wieku wyniosła 4 lata. Wszyscy pacjenci mieli rozpoznane zapalenie wyrostka sutkowatego, które częściej było po stronie prawej $(n=16)$. U 22 dzieci zapalenie wyrostka sutkowatego wystąpiło na tle ostrego zapalenia ucha środkowego, u 2 dzieci na tle przewlekłego zapalenia ucha środkowego (jedno dziecko było hospitalizowane trzykrotnie). Ropień podokostnowy wyrostka sutkowatego stwierdzono u 6 dzieci. Paracenteza była wykonana u 20 pacjentów, w 9 przypadkach wykonano antromasteidektomię. U wszystkich pacjentów prowadzono intensywną antybiotykoterapię dożylną.

Wnioski: Najczęstszym powikłaniem usznopochodnym u dzieci jest zapalenie wyrostka sutkowatego, które występuje głównie na tle ostrego zapalenia ucha środkowego. Postępowaniem z wyboru jest leczenie chirurgiczne i złożona antybiotykoterapia. Jeżeli nie doszło do perforacji błony bębenkowej $\mathrm{z}$ wyciekiem ropnym, powinna być zawsze wykonana paracenteza. $\mathrm{W}$ przypadku ropnia podokostnowego wyrostka sutkowatego wykonywana jest antromasteidektomia.

Piotr H. Skarżyński, Arkadiusz Wąsowski, Henryk Skarżyński, Łukasz Bruski, Irina Pierzyńska

Sesja $\mathrm{X}$

Telemedyczne rozwiązania $\mathrm{w}$ diagnostyce, leczeniu i rehabilitacji pacjentów po wszczepieniu implantów ślimakowych

Instytut Fizjologii Patologii Stuchu, Warszawa

Światowe Centrum Słuchu, Kajetany

Instytut Narządów Zmysłów, Kajetany

Klinika Otolaryngologii i Rehabilitacji Oddziału Fizjoterapii

Warszawskiego Uniwersytetu Medycznego

Cele: Celem pracy jest przedstawienie nowoczesnych możliwości diagnostyki i rehabilitacji, wykorzystujących rozwiązania telemedyczne u pacjentów z zaburzeniami komunikacyjnymi oraz po wszczepieniu implantów ślimakowych. Celem telemedycyny jest zmniejszenie kosztów diagnostyki, rehabilitacji i leczenia, przy zapewnieniu ich większej dostępności dla pacjenta i wysokiej jakości usług. Ustawienie procesora mowy musi odbywać się regularnie i dlatego większość pacjentów pokonuje daleką, męczącą i kosztowną drogę do kliniki. Jest to problemem szczególnie w przypadku dzieci, które po męczącej podróży nie chcą współpracować ze specjalistami, dlatego też opracowano możliwość „zdalnego ustawienia”. Istnieje również możliwość konsultacji na odległość z wykorzystaniem wideootoskopu. Kolejnym rozwiązaniem jest Domowa Klinika Rehabilitacji, pozwalająca przeprowadzić telerehabilitację i zdalnie monitorować postępy procesu rehabilitacji użytkowników systemu implantu ślimakowego.

Materiał i metody: Od marca do maja 2011 roku w ośmiu ośrodkach Krajowej Sieci Teleaudiologii przeprowadzono badania na grupie 94 osób dorosłych i starszych dzieci. Uczestnicy badania otrzymali do wypełnienia kwestionariusz. W większości $(94,6 \%)$ pacjenci przyznali, że jakość usługi była na wysokim poziomie i wyrazili zadowolenie z dobrej jakości połączenia audio-wideo i kontaktu $\mathrm{z}$ audiologiem. Większość pacjentów przyznała, że telefitting jest dobrą alternatywą dla standardowych wizyt kontrolnych. Tylko w $33 \%$ przypadkach ankietowani przyznali, że powinno się go stosować jako alternatywę pierwszego ustawienia, potwierdzając tym samym stanowisko autorów. W przyszłości aż 93\% pacjentów chętnie skorzysta $\mathrm{z}$ telefittingu.

Wnioski: Wyniki wskazują, że zastosowanie narzędzi telemedycznych zapewnia pacjentom szybką i profesjonalną opiekę zespołu specjalistów, dysponujących dużym doświadczeniem budowanym $\mathrm{w}$ trakcie wykonywania ponad 15 tys. operacji i ponad 300 tys. konsultacji rocznie. Wszystkie metody stanowią część pierwszej w świecie Krajowej Sieci Teleaudiologii.

Piort H. Skarżyński, Maciej Ludwikowski, Krzysztof Kochanek, Henryk Skarżyński, Adam Piłka, Roman Barylyak, Lucyna Karpiesz, Irina Pierzyńska, Kinga Wołujewicz

Sesja X

Pilotażowy program badań przesiewowych słuchu w Tadżykistanie i Kirgistanie wśród dzieci pierwszych i drugich klas szkoły podstawowej (7-8 lat)

\author{
Instytut Fizjologii Patologii Stuchu, Warszawa \\ Światowe Centrum Stuchu, Kajetany \\ Instytut Narządów Zmystów, Kajetany \\ Klinika Otolaryngologii i Rehabilitacji Oddziału Fizjoterapii \\ Warszawskiego Uniwersytetu Medycznego
}

Wstęp: W wielu krajach prowadzone są różnorodne programy, które pozwalają odpowiednio wcześnie wykryć ubytki słuchu i rozpocząć leczenie. W Polsce działania te są powszechne. Kraje wschodnie nie oferują takiej możliwości, a problemy ze słuchem wśród ich mieszkańców są bardzo częste. W związku z taką sytuacją zespół Centrum Słuchu 
i Mowy „Medincus”, współpracując ze Światowym Centrum Słuchu, przeprowadził pilotażowy program badań przesiewowych słuchu wśród dzieci szkół podstawowych (7-8 lat).

Materiał i metody: Badania przesiewowe słuchu wykonano w dwóch szkołach podstawowych w Duszanbe (Tadżykistan) i w trzech szkołach w Biszkeku (Kirgistan). Do badań wykorzystano Platformę Badań Zmysłów. W programach pilotażowych uczestniczyli lekarze otolaryngolodzy, którzy oceniali ogólny stan zdrowia dzieci.

Wyniki: W Duszanbe przebadano 143 dzieci (110 ze szkoły tadżyckiej i 33 dzieci ze szkoły rosyjskojęzycznej). U 25 dzieci ze szkoły tadżyckiej (tj. 22,7\%) uzyskano pozytywny wynik badania, natomiast w szkole rosyjskojęzycznej wynik ten to 9 dzieci $(27,3 \%)$. Łącznie na 143 dzieci uzyskano $23,7 \%$ pozytywnych wyników badania przesiewowego. W Biszkeku przebadano 300 dzieci z trzech szkół podstawowych. W pierwszej przebadano 43 dzieci - pozytywny wynik badania był u 7 dzieci (16,3\%). W drugiej liczba przebadanych dzieci wyniosła 50, a liczba pozytywnych wyników to 8 (16\%). W trzeciej zbadano aż 207 dzieci, a u $30 \mathrm{z}$ nich $(14,5 \%)$ wykryto problemy ze słuchem. Łącznie uzyskano 45 wyników pozytywnych, co stanowi $15 \%$ wszystkich przebadanych dzieci.

Wnioski: Wyniki uzyskane w ww. krajach charakteryzują się większą liczbą wyników pozytywnych w porównaniu z Polską. Rodzice dzieci z ubytkami słuchu nie zauważyli żadnych problemów ze słuchem (w Polsce 65\% rodziców ich nie zauważyło).

\section{Agnieszka Sońta, Anna Zakrzewska}

\section{Sesja X}

\section{Wpływ zaburzeń drożności nosa na wydolność oddychania u dzieci}

\section{Klinika Otolaryngologii Audiologii i Foniatrii Dziecięcej Uniwersytetu Medycznego $w$ Łodzi}

Wstęp: Częstą dolegliwością dzieci cierpiących na przewlekłe trudności w oddychaniu przez nos, niezależnie od przyczyny je powodującej, jest szybsze męczenie się lub nawet gorsza wydolność fizyczna w porównaniu z rówieśnikami. Dolegliwość ta jest jednak bardzo trudna do określenia i zmierzenia w sposób obiektywny.

Cel pracy: Celem pracy była ocena wykorzystania wskaźnika FEV1 dla obiektywizacji wydolności oddychania dzieci cierpiących na przewlekłe zaburzeń drożności nosa.

Materiał i metody: Badaniami objęto grupę 22 dzieci z przewlekłymi zaburzeniami drożności nosa spowodowanymi przewlekłym alergicznym nieżytem nosa (p.a.n.n.) - 12 lub zniekształceniami przegrody nosa - 10. Grupę kontrolną stanowiło 12 dzieci bez cech choroby alergicznej oraz zniekształceń anatomicznych w obrębie nosa. U wszystkich dzieci wykonano badanie przedmiotowe, podmiotowe, laryngologiczne oraz testy skórne $\mathrm{z}$ alergenami środowiskowymi, przeprowadzono badanie rynomanometryczne, pomiary FEV1 za pomocą pikflometru oraz ankietę SNAQ-11 wg JACA przed leczeniem oraz po 3 latach prowadzenia immunoterapii swoistej lub po upływie minimum 3 miesięcy od wykonania septokonchoplastyki.

Wyniki: W grupie dzieci cierpiących z powodu p.a.n.n., a także u tych, u których obserwowano nieprawidłowości anatomiczne nosa, stwierdzono istotne różnice dotyczące zarówno drożności nosa (ocenione rynomanometrią), jak i pomiaru FEV1 w porównaniu z grupą kontrolną. Zaburzenia drożności nosa i zaburzeń oddychania odpowiadały subiektywnej ocenie pacjentów dokonanych na podstawie ankiety rynologicznej. Badania wykonane po przeprowadzonym leczeniu, zarówno obiektywne jak i subiektywne, wykazały dobrą drożność nosa, a także zdecydowaną poprawę (do wartości prawidłowych dla wieku) wyników pomiaru FEV1.

Wnioski: Badanie rynomanometryczne połączone z oceną wskaźnika FEV1 może znaleźć zastosowanie w obiektywizacji wskazań do podjęcia leczenia przewlekłych zaburzeń drożności nosa, a uzupełnione kwestionariuszem SNAQ-11 w wielu przypadkach pozwala na ustalenie dominacji zaburzeń drożności nosa wynikających z reakcji błony śluzowej nad wynikającymi z nieprawidłowości anatomicznych nosa.

\section{Jarosław Szydłowski, Magdalena Prauzińska, Beata Pucher, Jagoda Kolasińska-Lipińska Sesja IX}

\section{Zespół pierwotnej dyskinezy rzęsek - problemy laryngologiczne}

Klinika Otolaryngologii Dziecięcej Katedry Otolaryngologii Uniwersytetu Medycznego im. K. Marcinkowskiego w Poznaniu

Pierwotna dyskineza rzęsek (PCD - Primary Ciliray Dyskinesia) określana też mianem zespołu nieruchomych rzęsek (ICS - Immotile Cilia Syndrome) jest konsekwencją zaburzeń budowy i funkcji rzęsek tzw. ciliopatii. Częstość występowania choroby szacuje się na 1 na 20-60 tys. osób, przy czym nie stwierdza się istotnego zróżnicowania geograficznego. Już od okresu noworodkowego u dzieci chorych obserwuje się zaburzenia oddychania oraz cechy przewlekłego nieżytu nosa. W okresie przedszkolnym i wczesnoszkolnym dołączają się objawy nawracającego wysiękowego zapalenia ucha środkowego oraz cechy przewlekłego zapalenia zatok przynosowych i zazwyczaj wtedy chorzy trafiają pod opiekę laryngologa. Objawy „laryngologiczne” są niespecyficzne dla tej jednostki chorobowej, a rozpoznanie jest stawiane zazwyczaj w ośrodkach pulmonologicznych.

Rola laryngologa jest jednak szczególna zarówno w procesie diagnostycznym jak i w leczeniu zaburzeń otologicznych i rynologicznych pojawiających się w trakcie naturalnego przebiegu choroby. W diagnostyce przesiewowej, obok powszechnie oznaczanego dziś poziomu tlenku azotu w powietrzu wydychanym, nadal wykonuje się test sacharydowy. Dla postawienia ostatecznego rozpoznania konieczne jest badanie ultrastruktury rzęsek oraz ocena ich ruchomości. 
Autorzy opisują grupę 24 chorych leczonych w Klinice Otolaryngologii Dziecięcej UM w Poznaniu. Przedstawiają wypracowane standardy współpracy z zespołem pulmonologów i genetyków. Omawiają postępowanie w przewlekłym zapaleniu zatok oraz wysiękowym zapaleniu ucha środkowego u dzieci z pierwotną dyskinezą rzęsek.

\section{Małgorzata Śmiechura, Renata Pepaś, Wiesław Konopka}

\section{Opóźnienie rozwoju mowy w grupie dzieci zakwalifikowanych do obiektywnej diagnostyki narządu słuchu}

\section{Klinika Otolaryngologii Instytutu Centrum Zdrowia Matki Polki $w$ Łodzi}

Materiał i metody: 41 dzieci (32 chłopców i 9 dziewczynek $\mathrm{w}$ wieku od 2. do 5. rż.) z opóźnionym rozwojem mowy przebadanych w celu wykluczenia niedosłuchu. Badanie podmiotowe, przedmiotowe laryngologiczne. Diagnostyka audiologiczna - audiometria impedancyjna, TEOAE, ABR, badania genetyczne.

Wyniki: Słuch w granicach normy stwierdzono u 27 (66\%) pacjentów, jedno dziecko obciążone było zespołem Prader-Willego. Pięcioro dzieci było z zaburzeniami neurologicznymi, w tym jedno z opóźnionym rozwojem psychoruchowym i 4 dzieci z rozpoznanym autyzmem. $Z$ wywiadu przeprowadzonego z rodzicami wynikało, że dzieci prawidłowo reagują na dźwięki, starsze dzieci wykonują polecenia, tylko występuje całkowity brak rozwoju mowy. Niedosłuch stwierdzono u 14 dzieci (36\%). W badanej grupie dzieci z niedosłuchem tylko troje nie było obciążone żadnymi czynnikami ryzyka uszkodzenia słuchu. U jednego dziecka zdiagnozowano zespól Ehlersa-Danlosa. Kolejne dziecko przebyło operację korekcyjną rozszczepu podniebienia, natomiast pozostałe dzieci obciążone były licznymi czynnikami ryzyka uszkodzenia słuchu. W grupie dzieci z głuchotą, u których zdiagnozowano niedosłuch i nie było istotnych obciążeń w wywiadzie, u jednego dziecka (chłopca) stwierdzono genetyczne podłoże niedosłuchu pod postacią delecji heterozygot.

Wnioski: 1) W wybranych przypadkach opóźnionego rozwoju mowy nawet przy braku istotnych czynników ryzyka uszkodzenia słuchu wskazana jest uzupełniająca diagnostyka genetyczna. 2) Najczęściej przyczyną opóźnionego rozwoju mowy w badanej grupie były czynniki środowiskowe.
Małgorzata Śmiechura, Małgorzata Strużycka, Renata Pepaś, Wiesław Konopka Sesja $\mathrm{X}$

\section{Ocena czynników genetycznych u dzieci z głuchota prelingwalną}

Klinika Otolaryngologii Instytutu Centrum Zdrowia Matki Polki $w$ Łodzi

Około 50\% wrodzonych zaburzeń słuchu może być uwarunkowana genetycznie, z czego $70-80 \%$ to niedosłuchy izolowane. Głuchota dziedziczna może pojawiać się jako recesywny niedosłuch prelingwalny czy dominujący postępujący niedosłuch postlingwalny.

Za około połowę przypadków niedosłuchu prelingwalnego, izolowanego odpowiedzialna jest pojedyncza mutacja genu GJB2 - delecja guaniny w pozycji 35 (35delG).

Cel pracy: Badanie wybranych mutacji w genie GJB2 i GJB6 w grupie osób (dzieci) z głuchotą prelingwalną oraz poszukiwanie nowych mutacji.

Materiał i metodyka: 74 dzieci w wieku od 6 do 16 roku życia, z podejrzeniem genetycznie uwarunkowanego niedosłuchu i głuchoty. Badanie podmiotowe, przedmiotowe laryngologiczne i diagnostyka audiologiczna (audiometria impedancyjna, TEOAE, ABR).

Materiał badawczy stanowiła krew obwodowa. DNA izolowano z $200 \mu \mathrm{l}$ krwi za pomocą zestawu QIAamp DNA Blood Mini Kit (Qiagen). Stężenie i jakość uzyskanego DNA oceniano spektrofotometrycznie (Picodrop). Badanie wybranych mutacji w genie GJB2 polegało na sekwencjonowaniu części kodującej zlokalizowanej w eksonie 2. W tym eksonie znajduje się większość mutacji związanych z DFNB.

Równolegle do sekwencjonowania genu GJB2 przeprowadzono reakcje PCR multiplex dla genu GJB6 w kierunku poszukiwania delecji fragmentu o długości $342 \mathrm{kB}$.

Wyniki: Obecność homozygoty 35delG stwierdzono u 31 dzieci, a heterozygoty u 4 osób. Brak mutacji w genie Koneksyny 26 stwierdzono u pozostałych 39 badanych. Nie stwierdzono innych mutacji. Rodzinne obciążenie wadą słuchu stwierdzono u $40 \%$ badanych.

Wnioski: Mutacje w genie GJB2 były w wysokim stopniu odpowiedzialne za dziedziczną izolowaną postać niedosłuchu głębokiego stopnia. Istnieje duża korelacja pomiędzy wynikami badań genetycznych (obecność mutacji Koneksyny 26$)$ a obciążającym wywiadem rodzinnym. 
Rafał Zieliński, Anna Zakrzewska

\section{Torbiele naskórkowe w okolicy podbródkowej u dzieci}

Klinika Otolaryngologii Audiologii i Foniatrii Dziecięcej Uniwersytetu Medycznego w Lodzi

Torbiele naskórkowe i skórne są zmianami powstającymi w wyniku implantacji naskórka w warstwie skóry właściwej lub błony śluzowej. Zmiany takie są rzadko opisywane w okolicy głowy i szyi w dnie jamy ustnej, rzadko w okolicy podbródkowej i podżuchwowej. U dzieci guzy te występują niezmiernie rzadko. W diagnostyce różnicowej należy brać pod uwagę torbiel przewodu tarczowo-językowego, limfatyczną malformację naczyniową (cystichygroma), torbiel środkową szyi, limfadenopatię, guz tarczycy, torbiel krtaniową, torbiel naskórkową i skórną szyi, ropień okolicy podżuchwowej, kamicę i zapalenie ślinianki podżuchwowej. Diagnostyka opiera się na dokładnym wywiadzie, badaniu laryngologicznym oraz badaniach obrazowych. Autorzy przedstawiają przypadki torbieli naskórkowych okolicy podbródkowej u dzieci leczonych operacyjnie w Klinice Otolaryngologii, Audiologii i Foniatrii Dziecięcej w Łodzi. Chłopiec lat 6 przyjęty do kliniki z powodu guza okolicy podbródkowej po stronie lewej zauważonej 6 miesięcy wcześniej. Zmiana była opisywana w badaniu USG jako lita, łącząca się ze ślinianką podjęzykową po tej samej stronie. Zmianę usunięto i przesłano do badania histopatologicznego, które potwierdziło rozpoznanie torbieli naskórkowej. Dziewczyna lat 14 przyjęta do Kliniki z powodu zmiany guzowatej okolicy podbródkowej w linii pośrodkowej od około 12 miesięcy. Zmiana była opisywana w badaniu USG jako grubościenna torbiel wypełniona jednorodną treścią litą. Zmianę usunięto i przesłano do badania histopatologicznego, które potwierdziło rozpoznanie torbieli naskórkowej.
Rafał Zieliński, Anna Zakrzewska

Sesja XV

\section{Obustronny perlak ucha środkowego u małego dziecka}

Klinika Otolaryngologii Audiologii i Foniatrii Dziecięcej Uniwersytetu Medycznego w Lodzi

Przewlekłe perlakowe zapalenie ucha środkowego jest najczęściej wynikiem niekontrolowanej atelektazji w części wiotkiej błony bębenkowej. Niekiedy perlak powstaje za niezmienioną błoną bębenkową, wzrastając w przednio-górnej części jamy bębenkowej. U małych dzieci perlaki wrodzone są wykrywane niezwykle rzadko. Często dopiero uszkodzenie aparatu przewodzącego dźwięk oraz pogorszenie słuchu i nawracające wycieki, będące wynikiem zakażenia perlaka, zwracają uwagę na chorobę ucha. Na tym etapie choroby nie można już ustalić rozpoznania perlaka wrodzonego. Choroba dotyczy najczęściej jednego ucha. Autorzy przedstawiają niezwykle rzadki przypadek obustronnego perlaka u małego dziecka leczonego w Klinice Otolaryngologii, Audiologii i Foniatrii Dziecięcej w Łodzi. Chłopiec w wieku 2,5 roku od około 3 miesięcy leczony był ambulatoryjnie $\mathrm{z}$ powodu wycieku $\mathrm{z}$ ucha lewego. $\mathrm{Na}$ podstawie badania klinicznego oraz tomografii komputerowej w Klinice stwierdzono u chłopca rozległy perlak ucha lewego. U chorego wykonano tympanoplastykę zamkniętą ucha lewego. Około pół roku po zabiegu operacyjnym przy jednej z kontroli stwierdzono wyciek ropny, ziarninę oraz perlak ucha prawego. W tomografii komputerowej stwierdzono zniszczenia kostne wyrostka sutkowego ucha prawego, nieopisywane przy uprzedniej ocenie tomograficznej kości skroniowych. 